\title{
INVESTIGACIONES ARQUEOLÓGICAS EN EL CASTILLO DE PASAMAYO: UN SITIO AMURALLADO CHANCAY EN EL VALLE BAJO DEL RÍO CHANCAY-HUARAL
}

\author{
Pieter VAN Dalen Luna ${ }^{\mathrm{i}}$ \\ Universidad NaCIONAL MAYOR DE SAN MARCoS \\ pvandalen2@hotmail.com
}

\section{RESUMEN}

Se presentan los resultados de las investigaciones con excavaciones en el sitio arqueológico Castillo de Pasamayo, un sitio caracterizado por presentar tres murallas circundantes. En los últimos años se ha identificado en los valles de Chancay y Huaura numerosos sitios de estas características, por lo que la información que presentamos aporta a la comprensión del patrón espacial, constructivo y funcionalidad.

Palabras Clave: Arqueología, valle Chancay-Huaral, cultura Chancay, sitios amurallados.

\section{Abstract}

We present the results of research with excavations at the archaeological site Castillo de Pasamayo, a site characterized by having three walls surrounding. In recent years it has been identified in the valleys of Chancay and Huaura numerous sites of this nature, so the information presented adds to the understanding of spatial pattern,construction and functionality.

KEYworDs: Archaeology, Chancay-Huaral valley, Chancay culture, walled sites.

i Arqueólogo por la Universidad Nacional Mayor de San Marcos. Ha realizado estudios de maestría en Arqueología Andina y Maestría en Estudios Amazónicos, así como doctorado en Ciencias Sociales. Es docente auxiliar en la EAP de Arqueología, Facultad de Ciencias Sociales de la Universidad Nacional Mayor de San Marcos y, en la actualidad, director del Museo de Arqueología y Antropología de la misma universidad. Es director del Proyecto de Investigación Chancay-Huaral-Atavillos (PIACHA) y director de la revista Kullpi. 


\section{UBICACIÓN DEL SITIO}

El sitio arqueológico Castillo de Pasamayo se encuentra ubicado en la margen izquierda del valle bajo del río Chancay-Huaral (la ONERN lo denomina así para diferenciarlo del río Chancay de Lambayeque: ONERN; 1969), en el distrito de Aucallama, provincia de Huaral. Se ubica casi en el rincón del valle en el subsector Aucallama-Pasamayo a pocos metros frente del imponente cerro de arena de Pasamayo, junto a la carretera variante Pasamayo. Se encuentra emplazado sobre un promontorio natural aislado de casi $40 \mathrm{~m}$ de altura con respecto al valle y al poblado actual de Pasamayo, cuya cima se ubica en las coordenadas UTM: 0258726E, 8716450N (Sistema WGS-84) y a 140 msnm (esquina del vano en "L").

Geográficamente, la zona que rodea el sitio, presenta un paisaje de valle bajo, caracterizado por el relieve llano con extensas zonas de cultivo, principalmente de maíz. El tipo de suelo de esta zona del valle, pertenece a la serie Pasamayo: suelo alcalino, muy profundo, de excelente drenaje y con un relieve topográfico casi plano. Por su ubicación, cerca del mar, presenta abundante influencia marina, presentando en los alrededores, humedales caracterizados por el afloramiento de aguas de la napa freática, como es el caso de los Baños de Boza y Gramadales. Los cerros adyacentes al sitio (Cerros Pasamayo), son áridos, sólo cuentan con algunas especies producto de la humedad invernal, adoptando la característica de lomas, cubriéndose de vegetación tipo Achupalla, principalmente (ONERN 1969).

\section{AnTECEDENTES DE Estudio EN LA ZONA}

La cuenca baja del río Chancay-Huaral presenta una larga y compleja ocupación cultural, desde periodos tempranos hasta la llegada de los españoles y la desestructuración de la civilización andina. Así, las diferentes culturas y pueblos que ocuparon este territorio supieron aprovechar de gran manera los recursos naturales que los diferentes ecosistemas les ofrecían, adaptándose; y mediante la acumulación de experiencias, desarrollaron un conjunto de tecnologías en los diferentes campos científicos, muchos de los cuales lamentablemente se perdieron para siempre con la llegada de los españoles y la desestructuración de la civilización local y regional. No existen muchas investigaciones sobre el valle Chancay y solo dos referencias sobre el sitio, motivo de la presente investigación.

La primera referencia la realiza el arqueólogo Hans Horkheimer, en su obra Identificación y bibliografía de sitios arqueológicos del Perú (Horkheimer 1965: 46), en la cual define al sitio como: "Sitio fortificado sobre un cerro. Los muros en parte son muy gruesos, de diferente composición. En la cumbre algunas construcciones de adobe. Al pie del cerro un cementerio con artefactos parcialmente del periodo de Transición. Al Este del cerro existió un extenso sitio, ahora destruido por la agricultura." La otra referencia sobre este sitio la realiza van Dalen (van Dalen 2008: 48): "[...] identificamos el sitio de Castillo de Pasamayo, un asentamiento ubicado en la cima de una estribación natural, con tres murallas que la rodean a diferentes alturas del cerro. Este sitio tiene sus similares en Acaray, en el valle de Huaura y Chanquillo en Casma. Se trata de un asentamiento de carácter ceremonial." Las investigaciones superficiales que realizáramos hace cuatro años, nos sugería que el sistema de murallas que presentaba el sitio podría corresponder al Formativo Tardío, hipótesis que fue desechada en la presente investigación.

Otros sitios arqueológicos, de similares características, han sido investigados en los últimos años en el vecino valle de Huaura, como es el caso de los sitios de Acaray y Cerro Colorado Grande (Brown 2010, 2011) y en el mismo valle Chancay a partir de fotos satelitales y prospecciones superficiales (Krzanowski 2008).

\section{Metodología de inVestigacióN}

A. Prospección: Se realizó con la finalidad de:

- Definir la sectorización del sitio a partir de los materiales culturales aflorantes, así como definir las áreas de intervención física mediante la excavación; así mismo identificar áreas que contengan material cultural superficial y que puedan ser indicadores de la presencia de otros restos arqueológicos en el subsuelo. 


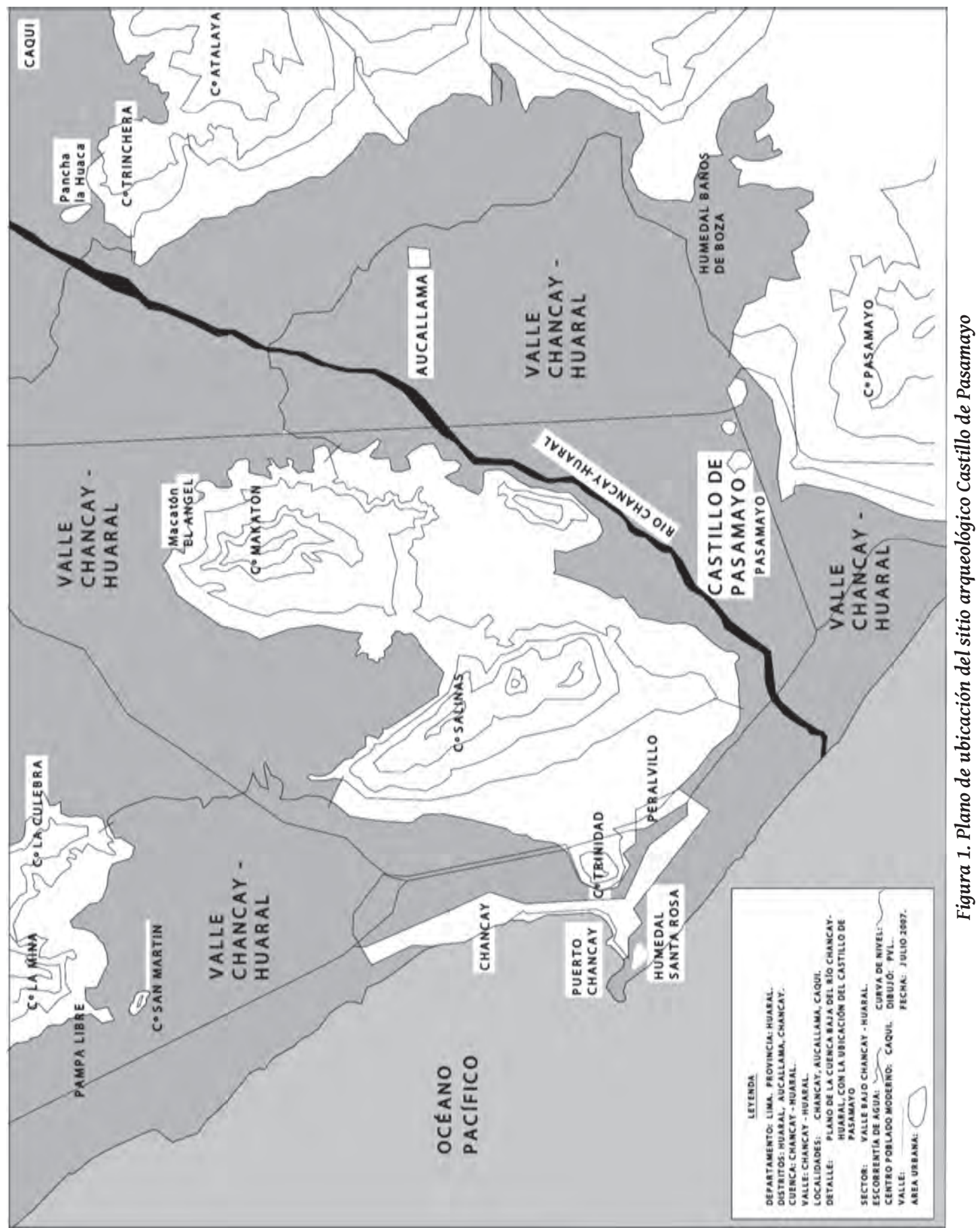


- Tratar de definir el carácter contextual de los hallazgos, así como su filiación cultural, cuando esta sea posible.

El recorrido de prospección permitió realizar la sectorización del sitio. Se realizó además en esta etapa el levantamiento topográfico y planimétrico del sitio con estación total y GPS Diferencial Milimétrico, a partir de los elementos arquitectónicos aflorantes, además de dibujos de planta, perfil y cortes de los elementos más representativos. Se ubicó el punto datum en la cima del cerro, desde donde se trazó el sistema de coordenadas.

B. Excavación: El método de excavación utilizado fue mediante diez unidades restringidas a 2x2 m. La disposición de las unidades fue en relación a la disposición de los elementos arquitectónicos. La excavación de los pozos de cateo se ejecutó siguiendo capas culturales, excavando hasta llegar a otra capa, siguiendo el mismo procedimiento, registrando elementos culturales y contextos. Los materiales recogidos durante las excavaciones fueron colocados en bolsas de polietileno con su información correspondiente. El registro de las unidades excavadas fue mediante dibujos de perfil, planta y elementos; fichas de registro de excavaciones; y registro fotográfico. El registro fotográfico de las excavaciones y de las estructuras de superficie fue con fotografías a color hechas con cámara digital, registrando cada toma en su respectiva ficha. Una vez concluida la excavación se colocó en el fondo de cada pozo un plástico grueso con las indicaciones del proyecto.

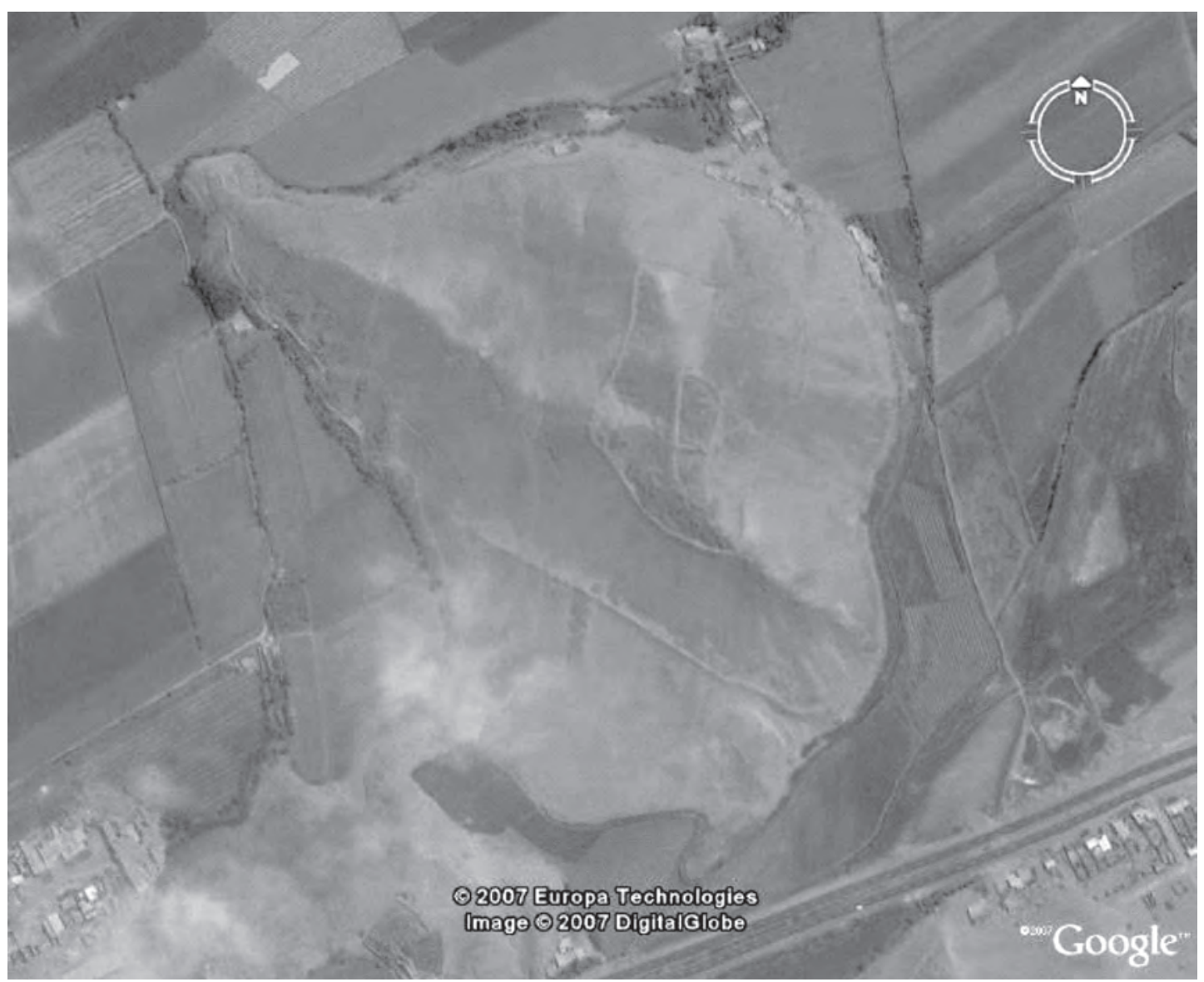

Figura 2. Foto satelital del sitio arqueológico Castillo de Pasamayo 
Para el proceso de registro del sitio, se utilizó las siguientes fichas de registro: Ficha de Registro del Sitio, Ficha de Registro Fotográfico, Ficha de Registro de Excavaciones, Ficha de Análisis Arquitectónico, entre otros. La Nomenclatura utilizada para el sitio de Castillo de Pasamayo fue C.P.

Cabe mencionar que inicialmente se propuso al Ministerio de Cultura la autorización de la excavación de unidades en área y trincheras, pero como siempre, por la ineptitud y total desconocimiento sobre arqueología de los funcionarios encargados de la revisión y aprobación del proyecto, nos obligaron a reducir las unidades a $2 \times 2 \mathrm{~m}$.

\section{MARCO TEÓRICO}

Wilson al definir los sitios con murallas en el valle de Santa, los llama fortalezas o sitios amurallados (Wilson: 1988). Margaret Brown, por su parte define a las fortalezas como aquellas rodeadas en su perímetro por muros, parcial o totalmente (Brown 2010: 172).

Son, hasta el momento, dos investigadores que vienen tratando la problemática de estos sitios en los valles de Chancay y Huaura: Margaret Brown V. (Brown 2009, 2010; Brown, Craig y Ascencios 2011) y Andrzej Krzanowski (Krzanowski 2008). Sin embargo, muchos otros autores han reportado la presencia de sitios amurallados en valles contiguos como la Fortaleza de Collique en el Chillón (Morales 1998), en el sitio de Chimú Cápac en el valle de Supe (Valckenier 1995), en el valle de Virú (Willey 1953), en los valles de Casma, Nepeña, Santa (Pozorski 1987; Proulx 1973, 1985; Wilson 1988, 1997; Ghezzi 2006). Hasta finales del siglo pasado, los investigadores coincidían en que los sitios de características amuralladas correspondían al Horizonte Temprano, y el hallar un sitio de estas características era un indicador de este periodo cultural. Brown ha sistematizado las investigaciones pretéritas definiendo la cantidad de sitios por valle correspondientes a este periodo: En el valle de Virú: 6 sitios; en Santa: 21; en Nepeña: 3; Casma: 34; Culebras: 2; Supe: 1, y Huaura: 6. Se trata de sitios ubicados en las cumbres y rodeados por entre 1 y 5 muros de defensa, edificados con piedras canteadas. Las fortale-

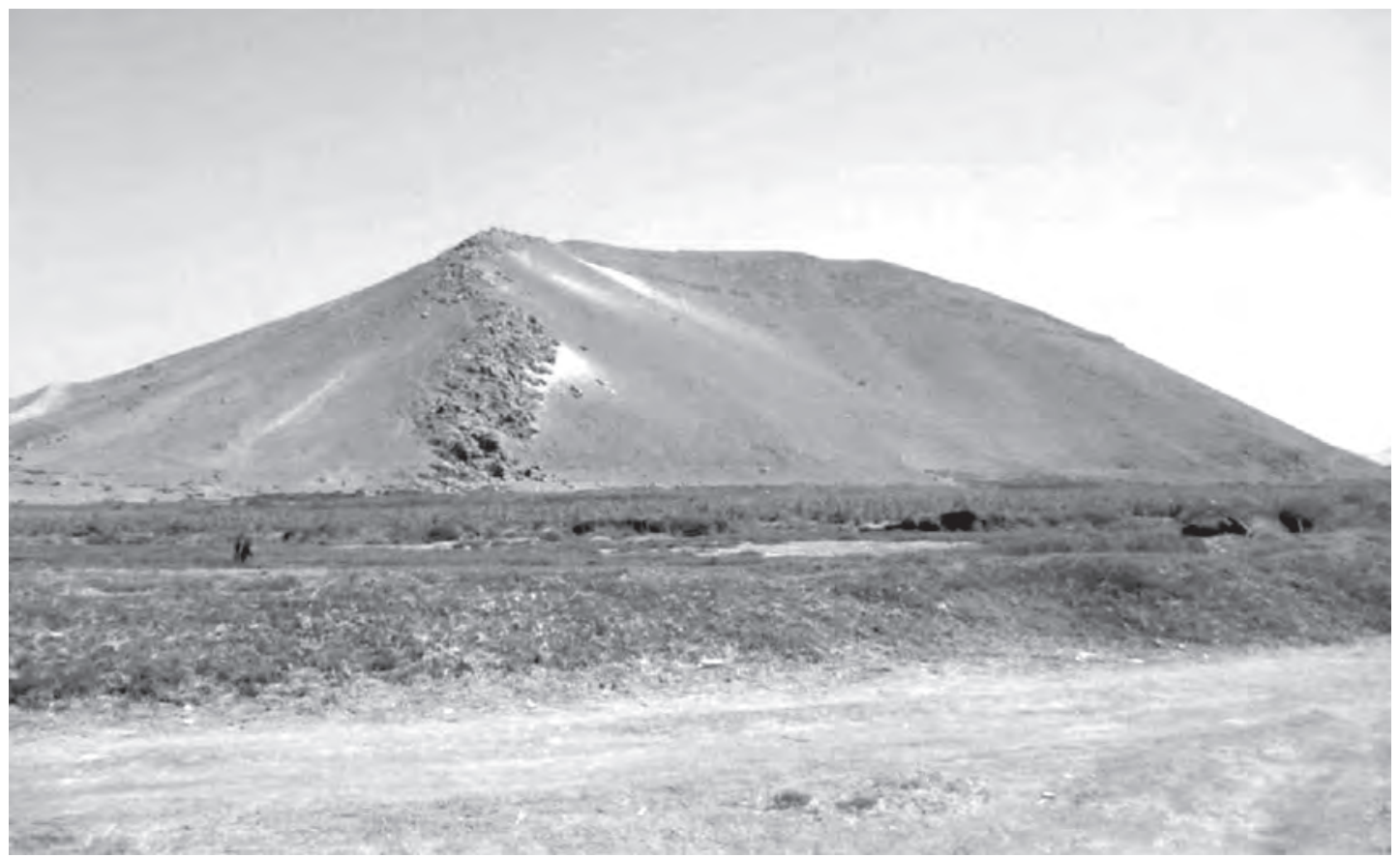

Figura 3. Vista panorámica del castillo de Pasamayo 


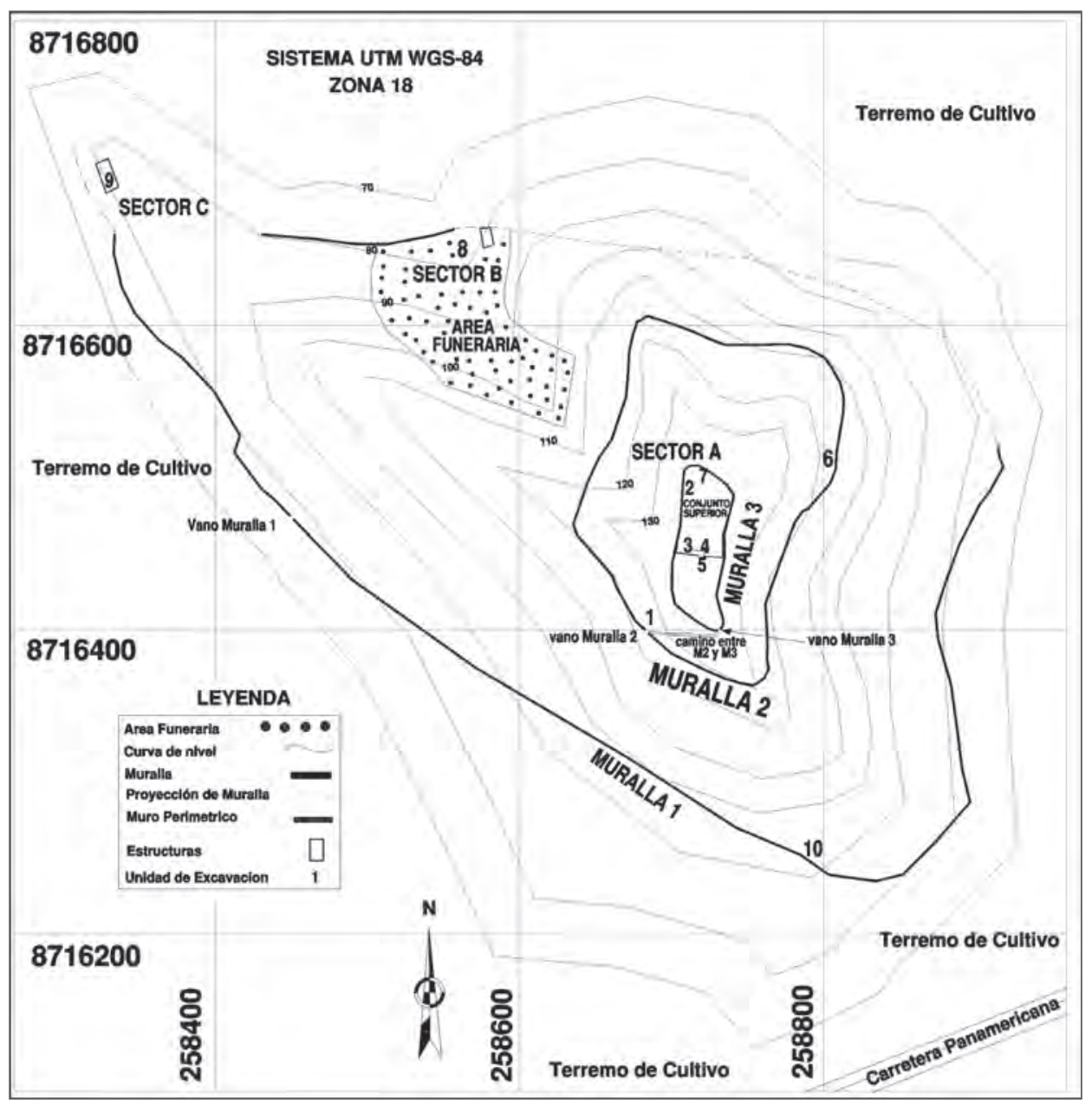

Figura 4. Plano del sitio arqueológico Castillo de Pasamayo

zas de los valles de Nepeña y Santa se ubican en el valle medio y cuenca alta; mientras que las ubicadas en los valles de Culebras, Supe y Huaura se hallan en el valle bajo (Brown 2010: 172-174).

Con respecto a los seis sitios amurallados del Horizonte Temprano en el valle de Huaura, Brown los caracteriza por ubicarse en las cumbres, tienen muros defensivos y acceso restringido. Estos sitios son: Acaray, Cerro Colorado, Vilcashuaura, Rontoy, San Cristóbal, y Costado Sur del Río; de los cuales cuatro se ubican en el valle bajo y son visibles entre sí. Los tres sitios ubicados en la margen norte del valle bajo tienen una cumbre con anillos de tres muros concéntricos, caracterizados por estar edificados a base de piedras canteadas unidas con argamasa y relleno de rocas medianas (Ibid: 176-178).

Margaret Brown define, además, la reocupación de sitios amurallados en el valle de Huaura, con patrones muy similares a los descritos, aunque de datación correspondiente al Intermedio Tardío. Estos sitios son los de Cerro Colorado y Acaray, el primero conformado por tres muros concéntricos muy destruidos, y el segundo con tres cumbres cada una de entre 1 a 3 muros concéntricos de defensa, cuya técnica de construcción es mediante capas alternas de material vegetal y piedras con relleno de piedras, basura y tierra. Acaray presenta parapetos, bastiones, acceso restringido y piedras para honda en superficie. Reporta además dos fechados radiocarbónicos tomados del material vegetal constructivo: 11601390 d.C. (Sector B, muro bajo) y 1400-1630 d.C. (muro principal del sector C). (Ibid: 182). 
Andrzej Krzanowski por su parte menciona la existencia de decenas de sitios de este tipo en los valles de Chancay y Huaura, los cuales son asociados a la cultura Chancay. Para el valle de Huaura registra un total de nueve sitios entre los que figuran: Acaray (Hu-56), Cerro Colorado (Hu-1), Cerro Eriazo A (Hu-80), Cerro Eriazo B (Hu-82), Vista Alegre (Hu-53), Hu-35, Hu-37, Hu-51, y Hu-96; mientras que para el valle de Chancay registra diez sitios, entre los que figuran: Cerro Pasamayo o Castillo de Pasamayo (Ch-3), Cerro San Pedro (CH-7), García Alonso (Ch-14), La Viña (Ch-21), Cerro Las Ondas (Ch-58), Cerro La Calera (CH-60), Cerro Gorgona (CH-54), Cerro San Cristóbal (Ch-43), Ch-17 y Cerro Mascarín (Ch-32). Sobre la funcionalidad de estos sitios, Krzanowski plantea que podría tratarse de sitios ceremoniales o incluso templos, pues no hay rasgos de residencia permanente de personas (con excepción de Acaray), además que los Chancay no se caracterizan por ser belicosos entre ellos, a lo más podría ser para defenderse de sus vecinos. (Krzanowski 2008: 75-95).

Krzanowski realiza una clasificación de los sitios "fortificados", según su complejidad espacial y arquitectónica en los siguientes tipos: ciudadelas, fortalezas, puestos de vigilancia o control y murallas extendidas; cada uno con un tipo de construcción diferente. En el caso de las ciudadelas, solo figura el caso de Acaray, se componen de construcciones internas. Las fortalezas o "castillos" se sitúan en colinas rodeadas de murallas concéntricas, pero sin restos de edificaciones internas, o son pocas y distantes entre sí, no hay evidencia de una ocupación permanente, habrían sido edificadas en el Formativo u Horizonte Medio, pero reocupado hasta el Tawantinsuyu, tiene accesos restringidos y
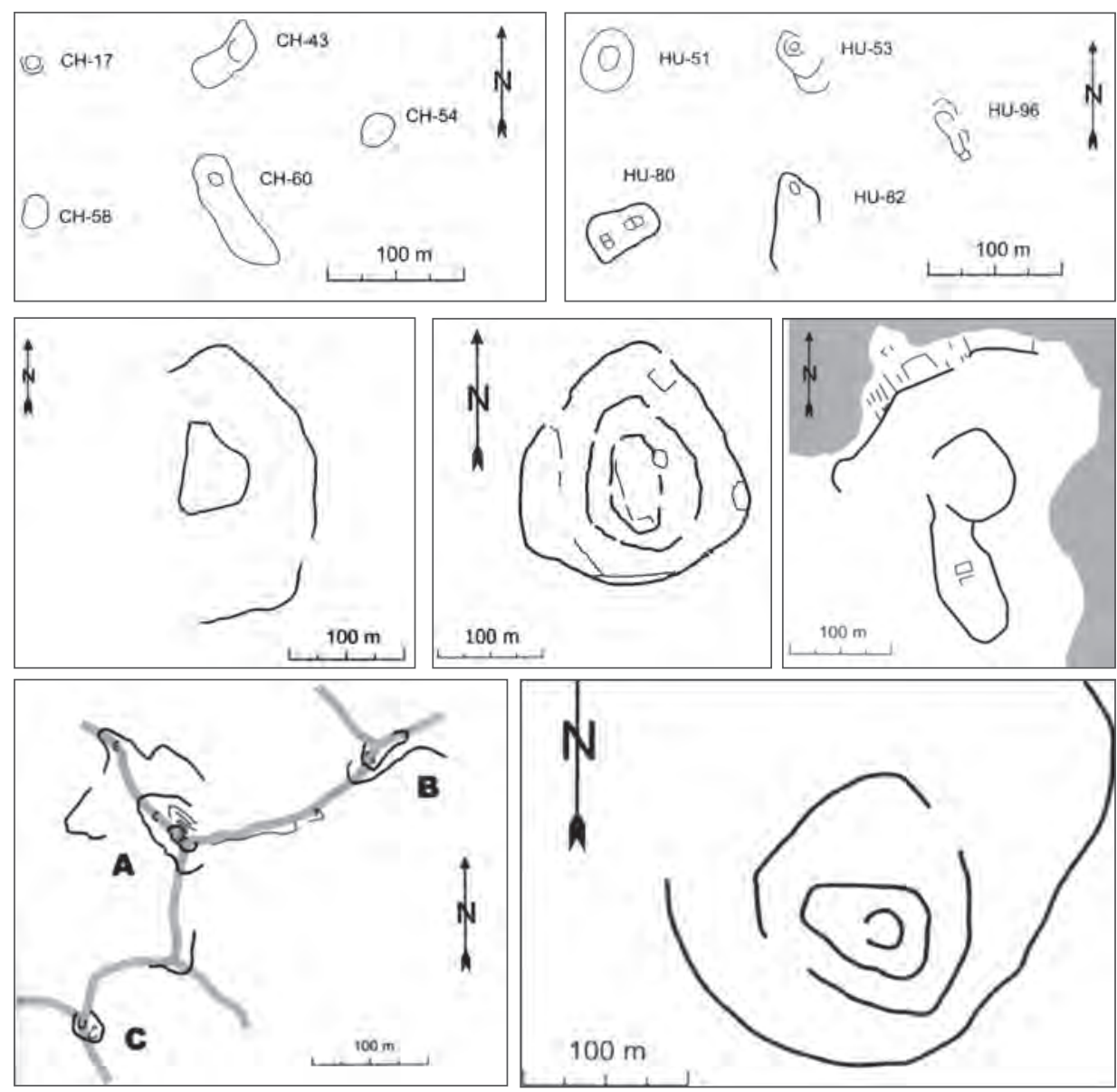

Figura 5. Cerro Mascarín (izquierda) y San Pedro (derecha), todos en el valle Chancay-Huaral 
sus muros están elaborados en piedra grande en bruto. Los puestos de vigilancia o control son de pequeñas dimensiones, de un solo recinto con doble pared concéntrica (entre 100 y $200 \mathrm{~m}^{2}$ ), ubicados en la cima de los cerros más elevados que circundan el valle desde donde se tiene una vista panorámica del territorio. (Ibid: 82-95).

A partir de las definiciones dadas por los diferentes autores a este tipo de edificaciones es necesario realizar una conceptualización de los mismos: La muralla está definido por el Diccionario de la RAE como un muro u obra defensiva que rodea una plaza fuerte o protege un territorio. Son todo tipo de fortificaciones edificadas defensivamente para impedir el paso o ataque militar, tratándose de una pared alta, firme y gruesa, de imponente imagen. La función principal era la de proteger y dar seguridad a todas aquellas construcciones ubicadas al interior de su perímetro; aunque había casos en que servían para delimitar un territorio. Pueden ser cerradas (en la mayoría de los casos) o extendidas y abiertas. En algunos casos puede presentar puestos de vigilancia. El término es un diminutivo de ciudad: ciudad pequeña.

Por su parte las fortalezas son aquellas edificaciones fortificadas con fines defensivos militares. Sus orígenes se remontan a la Edad Antigua del Viejo Mundo, como en Roma, siendo luego de uso expandido por toda Europa, como entre los Francos y Sajones, y ya universalizado en la Europa Feudal. El fenómeno de los sitios fortificados de la alta Edad Media como centros de coerción feudal con una funcionalidad militar, de control del territorio y de las comunidades campesinas, así como los procesos políticos y socioeconómicos que conducen a su nacimiento e implantación, son aspectos ampliamente estudiados en algunas regiones europeas, especialmente en Italia (Gutiérrez y Suárez 2007:3).

Los castillos también tienen una definición relacionada con la actividad militar y defensiva. El diccionario de la RAE lo define como: "[...] un lugar fuerte, cercado de murallas, baluartes, fosos y otras fortificaciones". Hay varias edificaciones que cumplen la misma función como: el alcázar, la torre, el torreón, el atalaya, el fuerte, el palacio fortificado, la ciudadela, la alcazaba, etc. El castillo convencional es un recinto amurallado que encierra un patio u otras edificaciones (pueden ser habitacionales), comprendiendo además torres. Desde el periodo Neolítico se construyen fortificaciones sobre colinas, pero es con el Imperio Romano que su uso va a ser más extendido (castrum). Fue en la edad media cuando los castillos van a adquirir tanto una función militar como residencial, de uso de los señores feudales y reyes, constituyéndose en "palacios fortificados", a veces ubicado en medio de centros urbanos o en lugares elevados y aislados con fines defensivos. Así, los castillos se convierten en el símbolo del sistema feudal, y la relación servil. Entre los elementos convencionales que constituyen un castillo figuran: La cerca perimétrica, la torre del homenaje o principal que sirve de residencia, el patio de armas en la parte central, el pozo de agua, la barbacana o fortificación adicional, el puente de acceso, parapetos, entre otros. En este sentido no estamos de acuerdo con el nombre del sitio "Castillo de Pasamayo", sin embargo es necesario conservarlo ya que así lo bautizó Horkheimer en la década del 60.

Como hemos visto en las definiciones, los términos fortalezas, ciudadelas y castillos, están referidos a conjuntos arquitectónicos de carácter defensivo, desarrollados principalmente entre finales de la Edad Antigua y la Edad Media, y que simbolizó el sistema feudal imperante en Europa en estos siglos, sistema basado en la relación señor-siervo a través del tributo personal. En este sentido consideramos que estas categorías no pueden ser aplicables para la civilización andina prehispánica, cuyas formaciones sociopolíticas tuvieron procesos sociales e instituciones propias. En todo caso el término que más se ajustaría para definir a un sitio o enclave militar, ofensivo o defensivo, sería el Pucara. Este tipo de edificación es muy difundido en los periodos Intermedio Tardío y en el Tawantinsuyu, conocido en el Ecuador con el nombre de Churu. No presentan un patrón definido, su distribución espacial puede ser variada, pero se denominan así a todos los edificios de carácter militar ofensivo o defensivo, ubicado generalmente en la cima de los cerros (aunque hay algunos en lugares llanos). Las Pukaras fueron ampliamente utilizadas por los cuzqueños en el proceso de conquista de las naciones andinas y su anexión al Tawantinsuyu, así como por estas naciones para defenderse. 


\section{COMPONENTES DEL SITIO ARQUEOLÓGICO Y EXCAVACIONES}

En base a las características de la disposición de los elementos arquitectónicos y los materiales observables en superficie, hemos procedido a sectorizar el sitio en tres sectores:

1. Sector "A": Este sector se ubica en la cima del cerro y laderas medias. Se encuentra rodeado por tres murallas. En la parte superior del cerro, está la muralla 3 a su vez circundada por la Muralla № 2, la cual también da la vuelta por toda la extensión del cerro. Las murallas se encuentran en buen estado de conservación, llegando a tener hasta $3 \mathrm{~m}$ de altura, edificadas a base de piedras canteadas unidas entre sí con argamasa de barro. La parte superior se encuentra encerrada por la tercera muralla, a la cual se superpone un muro perimétrico que ocupa la mitad septentrional de la cima, que encierra al conjunto superior. Por su parte en el lado meridional de la cima hay un espacio a modo de patio de planta irregular y 36,20 m de largo (eje este-oeste, al nivel del vano de acceso al conjunto superior y el vano de acceso a la muralla 3), por 23,70 m de ancho (eje este-oeste. Hacia el flanco suroeste del cerro desciende desde la cima hasta su base un afloramiento rocoso, el cual se constituyó en la cantera desde donde se obtenía las piedras para construcción, notándose tanto los cortes como los bloques líticos obtenidos por percusión, algunos de ellos dispersos por encima de la muralla 2.

La muralla 3: Se trata de un muro que cumple la función de muro de contención de la plataforma superior (cima), y que al elevarse a la superficie de esta se convierte en un muro de dos caras. Está edificado a base de piedras canteadas medianas dispuestas en hileras horizontales alternadas con capas de cañas y totora dispuestos en posición horizontal con las puntas hacia los paramentos. En la actualidad se encuentra en mal estado de conservación, solo presenta 1,80 m de alto, y bordea toda la cima del cerro; mientras que tiene un grosor de 2,10 m. Presenta un vano en mal estado de conservación ubicado al extremo suroeste de la cima, las jambas están definidas por dos piedras canteadas con las caras planas orientadas hacia el acceso. Este vano tiene 1,20 m de ancho. Hasta este acceso llega el camino proveniente desde el vano de la muralla 2. La muralla 3 tiene un largo total de 215,34 $\mathrm{m}$ lineales en su sección media.

El conjunto superior: Se encuentra delimitado por el muro perimétrico, de piedras canteadas, con un adosamiento en la parte interna de una banqueta de adobes paralelepípedos e irregulares, de 0,25 $\mathrm{m}$ de ancho y un largo total de 172,78 m lineales. Ocupa la mitad septentrional de la cima del cerro. Es de forma irregular, de 50,82 $\mathrm{m}$ de largo (eje norte-sur) por 33,70 $\mathrm{m}$ de ancho (eje este-oeste). El acceso es por el lado suroeste y es mediante un pasadizo en "L" (luego de ingresar en dirección este por 6,10 m cambia de dirección al norte en un tramo de 8,90 m de largo), de 2,80 m de ancho, delimitado por muros de 1,40 m de alto, en mal estado de conservación. Estos muros son de características similares a los de las murallas, y son los mismos muros perimétricos que se prolongan hacia el interior del conjunto superior. El vano de acceso presenta una rampa, definida por la Unidad de Excavación 5 cuya secuencia estratigráfica es: Capa S: Capa eólica, de color beige claro, de un grosor entre 0,07 y 0,01 m, entremezclada con material murario de derrumbe. No presenta materiales culturales. Capa A: Capa de tierra compacta (por acción eólica pluvial), de color beige claro. Contiene lentes de coloración marrón en la esquina suroeste. Está entremezclada con numerosas piedras producto del colapso de muros. No se encontró material cerámico, solo material orgánico. Presenta un grosor de entre 0,05 y 0,09 m. Capa B: Piso a desnivel a manera de rampa, con inclinación de norte a sur. Presenta material cerámico incrustado (Chancay engobe blanco). La coloración del piso es beige claro, de consistencia compacta y presenta un grosor máximo de 0,05 m. Capa C: Relleno de adobes paralelepípedos (de 0,20 x 0,15 m) que se encuentran sin una disposición uniforme, colocados y rellenados con barro. Sólo se retiró el piso (Capa B) en un pequeño espacio de 0,40 $\mathrm{m}$ por $0,40 \mathrm{~m}$, en la esquina noreste de la unidad, a fin de definir el relleno. La secuencia de este relleno 

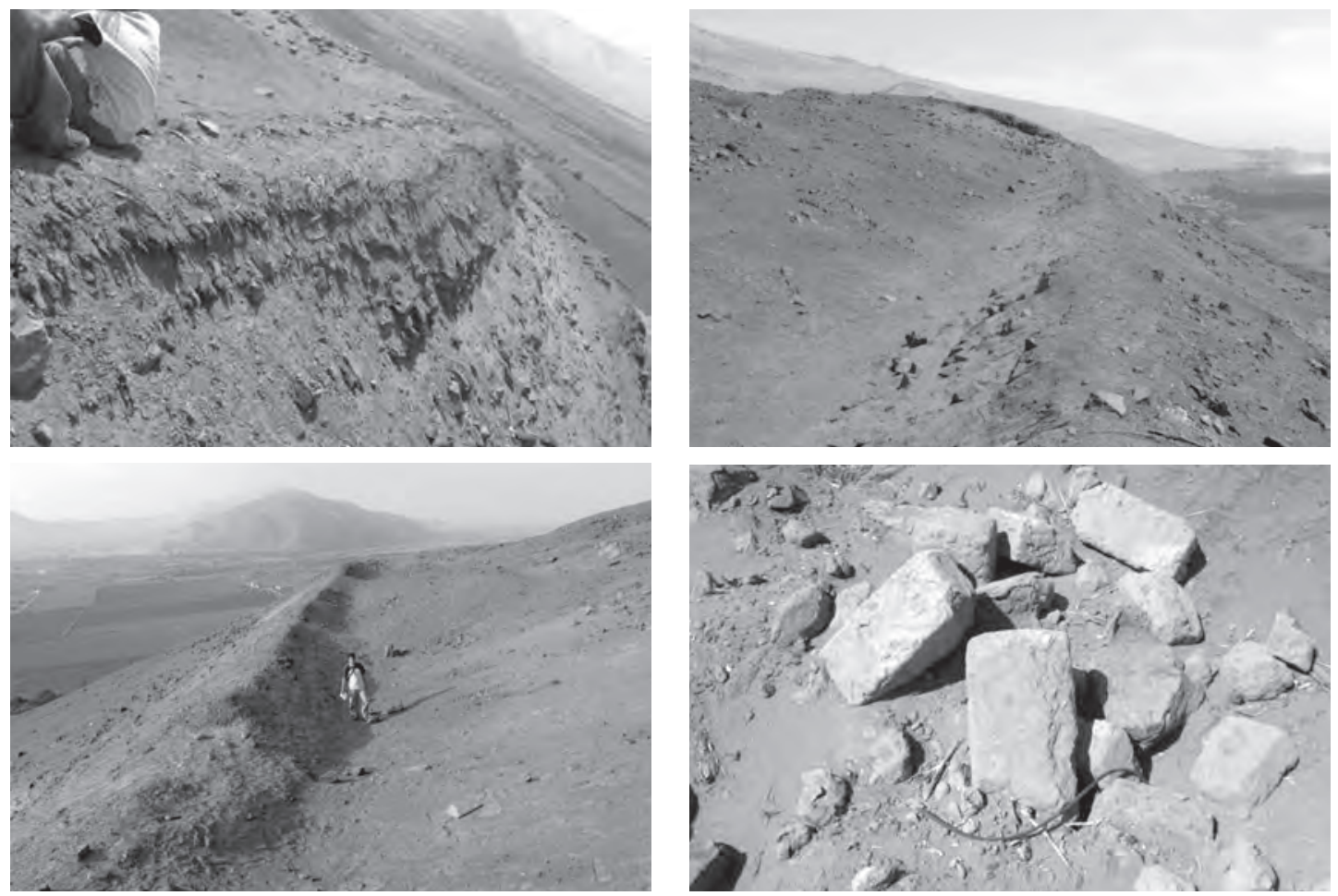

Figura 6 (Superior izquierda) y Figura 7 (Superior derecha): Vista del muro perimétrico del conjunto superior, en los lados noreste y noroeste, respectivamente. Figura 8 (Inferior izquierda): Vista panorámica parcial del conjunto superior, lado norte. Figura 9 (Inferior Derecha): Adobes identificados en superficie, hallados en un huaqueo. Son adobes de características Chancay.

se prolonga en las otras unidades emplazadas en el acceso. Se encontró dentro del relleno un fragmento cerámico de engobe blanco (Chancay). Tiene un grosor entre 0,10 a 0,28 m. Capa D (roca madre): Roca madre geológica, compacta y de color gris.

En el fondo del vano y donde el acceso en "L" cambia de dirección al norte se emplazó la unidad 4, cuya secuencia es similar a la de la unidad 5: Capa S: similar a la unidad 5 aunque entremezclado con restos de achupalla y malacológicos, de un grosor entre 0,03 m y 0,05 m. Capa A: La misma capa de la unidad 5, entremezclada con piedras colapsadas de los muros, restos de totora alineadas y dobladas en

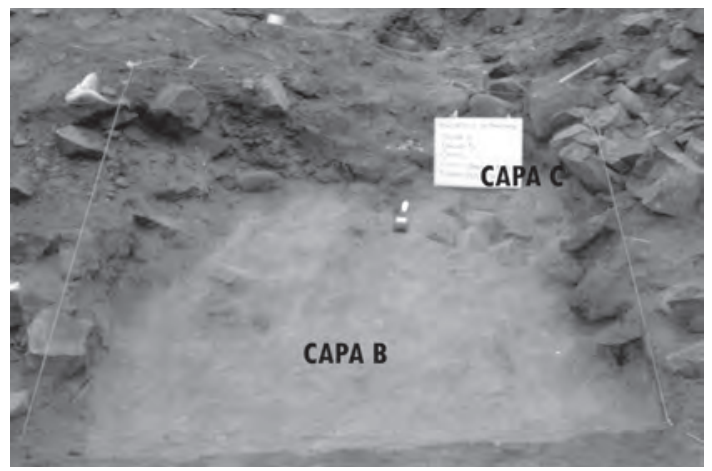

Figura 10 (Izquierda): Vista de la capa superficial de la unidad 5. Figura 11 (Derecha): Capas B (Piso) y C, unidad 5. 
posición horizontal, aflorantes del muro norte colapsado, y algunos fragmentos cerámicos. El grosor es entre 0,20 y 0,40 m. A partir de la culminación de esta capa se redujo la unidad a 1x1 en la esquina suroeste. Capa B: El mismo piso, con inclusiones de restos malacológicos (marinos) y fragmentos cerámicos, de 0,08 m de grosor. Capa C: Relleno preparatorio del piso, formado por compactación de piedras pequeñas y adobes pequeños (de 0,15 por 0,09 m: de la cultura Chancay). Esta capa no se excavó en su totalidad.

Antes que el acceso en "L" ingrese al conjunto superior se excavó la unidad 3, cuya secuencia es: Capa S: De origen eólico, color beige claro, consistencia suelta y de un grosor entre 0,10 a 0,21 m. Capa A: Tierra de color beige oscuro, semicompacta, y de un grosor de 0,22 m, entremezclado con restos vegetales. Capa B: Capa de tierra marrón oscuro, de consistencia semicompacta entremezclada con algunas piedras pequeñas, así como materiales malacológicos, botánico, carbón y fragmentería cerámica.
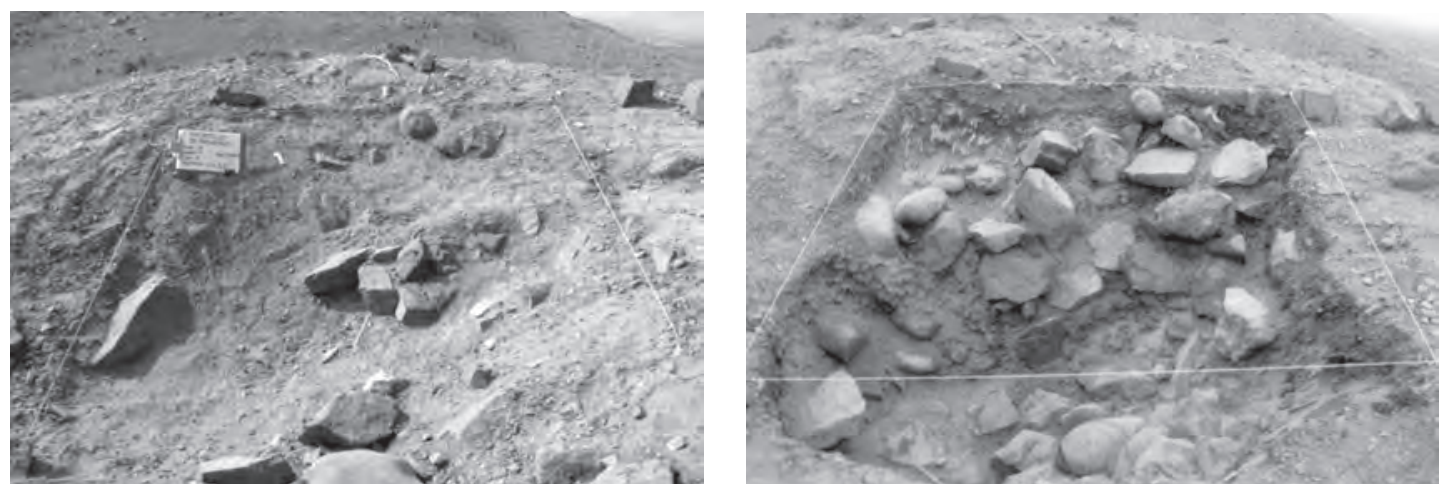

Figura 12 (Izquierda): Vista de la capa superficial unidad 4. Figura 13 (Izquierda): Vista final de la unidad 4, donde se puede apreciar el colapso parcial del muro.

Tiene un grosor de de 0,07 m. Capa C: Capa de color beige, semicompacta, de 0,15 m de espesor. Se halló fragmentos de adobe, además se podía visualizar la parte superior del muro 1. Se observa abundantes piedras producto del colapso de los muros. Capa D: Capa de tierra rojiza entremezclada con abundantes piedras producto del colapso de muros. Tiene un grosor de 0,35 m. En asociación a esta capa está la base del muro 1. Muro 1: Conformado por un alineamiento de cantos rodados y piedras canteadas mampuestas con argamasa de barro y restos vegetales. Las dimensiones del muro son: 0,48 $\mathrm{m}$ de ancho, 0,34 $\mathrm{m}$ de altura y 0,98 $\mathrm{m}$ de largo. En la parte interna se encontró un piso de 0,05 $\mathrm{m}$ de grosor, no bien definido. Capa E: Roca madre de origen geológico.
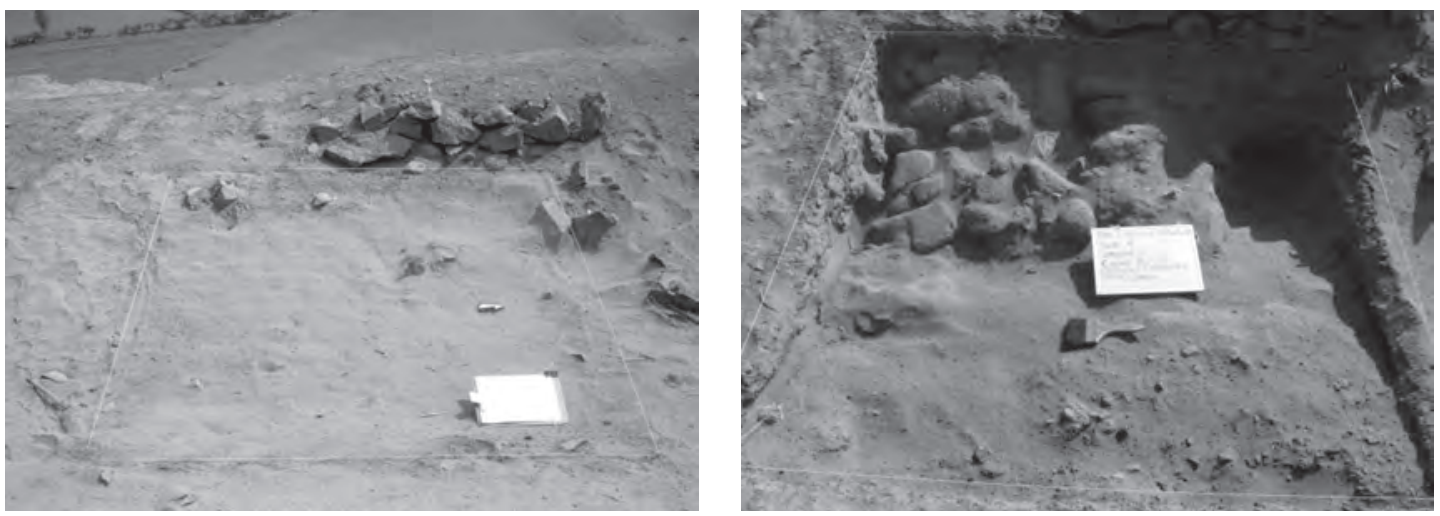

Figura 14 (Izquierda): Capa superficial de la unidad $N^{\circ} 2$ cuadriculada. Figura 15 (Derecha): Vista del elemento, capa C. 
En el interior del conjunto superior (lado septentrional), junto al muro perimétrico, se excavó la unidad 2, cuya secuencia estratigráfica es la siguiente: Capa S: De origen eólico y color beige claro, de granulometría fina con presencia de pequeñas piedrecillas, de un grosor entre 0,03 a 0,08 m. Capa A: De tierra compactada (por acción de las lluvias), de color beige y un grosor entre 0,04 y 0,10 m. La parte central de la unidad se presenta disturbada. Capa B: Capa de ceniza entremezclada con algunas piedras pequeñas, así como materiales malacológicos y botánico. La capa es de coloración negra y en algunas partes rojiza. Tiene un grosor de entre 0,04 y 0,12 m. Capa C: Se trata de un elemento arquitectónico de adobes, a modo de banqueta, adosado al muro perimétrico. El ancho de este elemento abarca la mitad septentrional de la unidad. Tiene una altura de 0,25 m. Estos adobes son paralelepípedos, de regular tamaño (Chancay), aproximadamente $0,20 \mathrm{~m} \times 0,30 \mathrm{~m}$, dispuestos de manera desordenada. Capa D: Apisonado de granulometría fina, de color beige, con inclusión de algunas piedrecitas. Tiene un grosor de 0,03 m. Capa E: Roca madre de origen geológico.

Por su parte en el extremo oriental interno del conjunto superior, junto al muro perimétrico se excavó la unidad 7: Capa S: Tierra suelta eólica, de color beige claro, y un espesor mínimo de 0,02 m y máximo de 0,07 m. Durante el proceso de remoción de la capa se pudo encontrar abundante vegetal contemporáneo como panca de maíz, así como excremento de cuy. Se halló además fragmentos cerámicos y malacológicos. Capa A: Apisonado que presenta su mejor consistencia en el lado sur de la cuadricula y está constituido por tierra y arena de color beige claro, de contextura semi suelta, entremezclado con material cerámico y malacológico. Tiene un grosor de entre 0,02 y 0,12 m. Lente de cenizas: debajo de la capa A, que se extendió en la tercera parte de la cuadrícula hacia el lado sur, de un grosor de entre 0,02 y 0,09 m. Se halló en el interior restos vegetales quemados. Capa B: Elemento arquitectónico, adosado al muro perimétrico, con adobes de diversas formas, ubicado en la mitad noreste de la cuadricula. Se observó diversos adobes largos unidos con un conglomerado de tierra y barro. Corresponde al mismo elemento que conforma la capa $\mathrm{C}$ de la unidad 2. Tiene una altura de 0,20 m. Capa C: Capa de tierra suelta de color beige y abundante cascajo debido a la descomposición de la roca madre sin asociación a algún tipo de material cultural. Posee un grosor de entre 0,02 m y 0,18 m como máximo. Capa D: Roca madre identificada en el lado sur de la unidad.

Camino entre las murallas 2 y 3: Entre las murallas 2 y 3, lado occidental del cerro, discurre un camino que asciende desde el vano de la segunda muralla al de la tercera, ascendiendo de manera recta por entre los afloramientos rocosos. Tiene un ancho aproximado de dos metros y se nota en algunas zonas el corte hecho en estos afloramientos. Este camino toma dirección ascendente al sur.
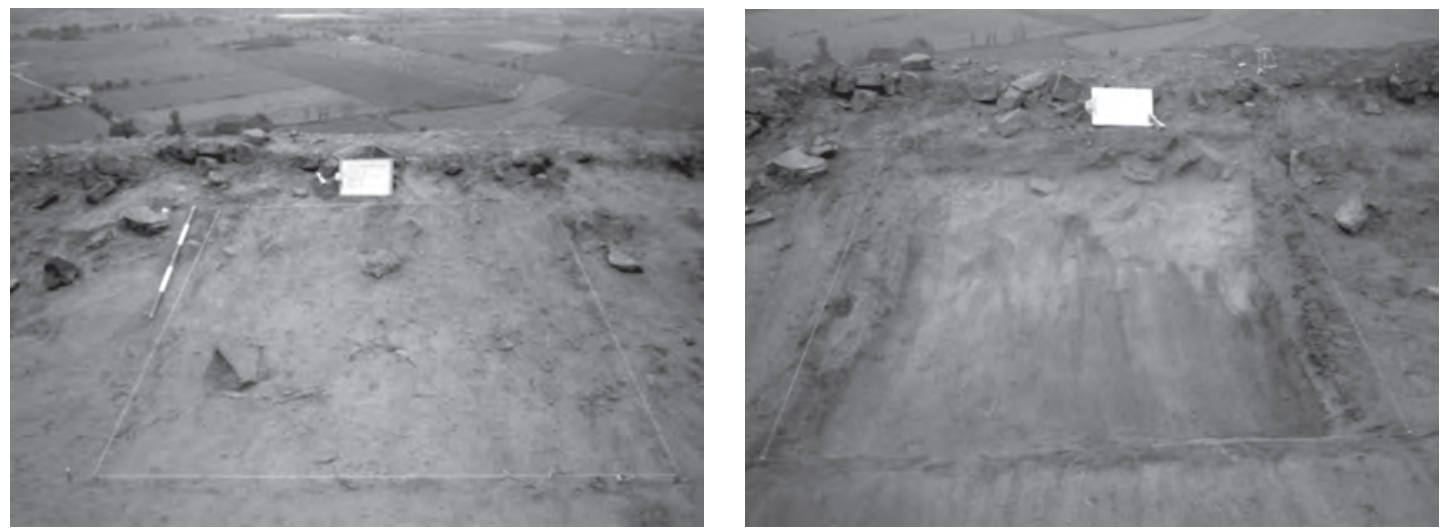

Figura 16 (Izquierda): Capa superficial de la unidad 7 asociada al muro perimetral. Figura 17 (Derecha): retiro de la capa A en la parte norte en la cual se comienza a observar algunos pedazos de adobes (Capa B). 
La segunda muralla: La segunda muralla se ubica por debajo del nivel de la tercera, a $15 \mathrm{~m}$ por debajo de su nivel, rodea el cerro por todos sus flancos. Está edificado a base de piedras y vegetales, conformando hileras horizontales alternadas. Tiene 1,30 $\mathrm{m}$ de ancho en promedio, y hasta $3.10 \mathrm{~m}$ de alto, así como un largo total de $686,11 \mathrm{~m}$. En algunos tramos se presenta plano, aunque en el lado norte desciende para ascender por el lado occidental. Cumple la función de muro de contención y tiene camino epimural. Presenta un vano de acceso localizado hacia el lado noroeste, de 2,80 $\mathrm{m}$ de ancho. Al ingresar por este vano se asciende por un camino hasta el vano de la Muralla 3. Se aprecia en los alrededores del vano abundante concentración de Tillandsia s.p. (achupalla). Justamente en el vano de acceso a la segunda muralla se excavó la unidad 1, que permitió definir sus características dimensiones.La secuencia estratigráfica identificada en esta unidad es la siguiente: Capa S: Compuesta por arena fina, de origen
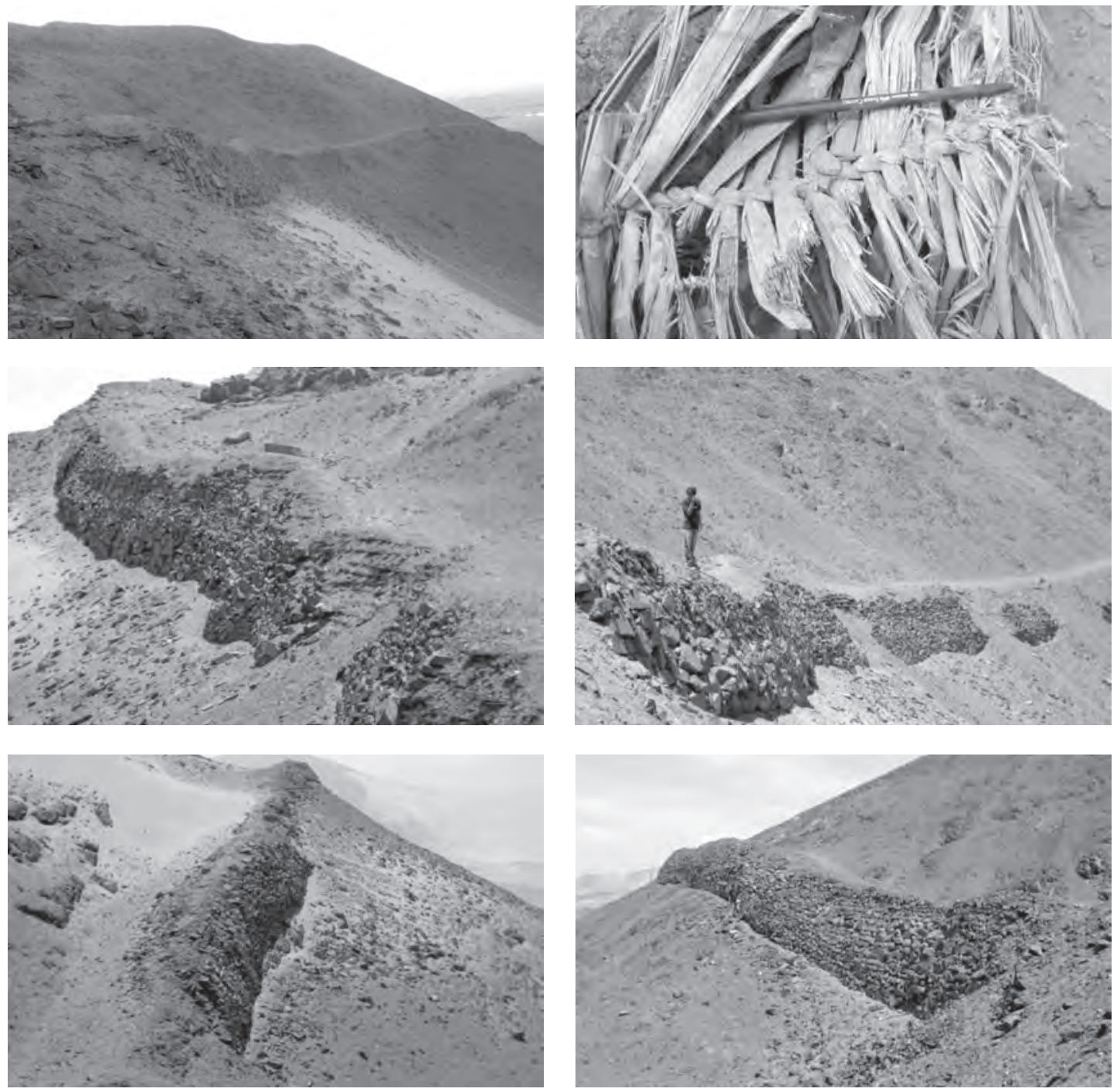

Figura 18 (Superior Izquierda): Vista de la muralla 2, lado sureste. Figura 19 (Superior Derecha): Vista de totora trenzada, identificado como material constructivo en la muralla 2. Figura 20 (Centro Izquierda) y Figura 21 (Centro Derecha): Muralla 2, vistas en el lado suroeste y sureste, respectivamente. Figura 22 (Inferior Izquierda) y Figura 23 (Inferior Derecha): Muralla 2, vistas en el lado este y noreste, respectivamente. 
eólico, de entre 0,20 a 0,25 m de grosor. Presenta una coloración beige clara y es de textura fina. Capa A: Delgada capa de cenizas, la cual se extiende sólo en el lado oriental de la unidad, mas no en toda ésta. Presenta una coloración negra, de textura fina, se pudo observar algunos restos de material botánico (achupalla). Tiene un grosor de entre 0,10 a 0,15 m. Capa B: Capa de acumulación de material botánico (achupalla), mezclada con arena fina de color beige. Esta capa se encuentra inmediatamente debajo de la capa de ceniza. Tiene un grosor de entre 0,05 a 0,10 m. Capa C: Capa de tierra entremezclada con abundantes piedras de gran tamaño, producto del colapso de la muralla (piedras de 0,80 m x 0,40 m. en promedio). No se culminó la excavación por lo frágil de la capa de arena, solo se profundizó 0,50 m.

Por su parte hacia el otro lado del cerro (sur) se excavó la unidad 6, cuya secuencia estratigráfica fue la siguiente: Capa S: Tierra semicompacta (por su ubicación en el camino epimural, transitado hasta la actualidad), de origen eólico, entremezclada con ripio y pequeños gránulos de roca. Esta capa posee color beige claro, y un espesor mínimo de 0,02 m y máximo de 0,07 m. Durante el proceso de remoción de la capa se pudo encontrar tiestos de cerámica así como fragmentos malacológicos y material vegetal contemporáneo. Capa A: Apisonado de tierra de color beige claro, entremezclado con inclusiones de piedras, de contextura semi compacta y de un grosor entre 0,04 y 0,10
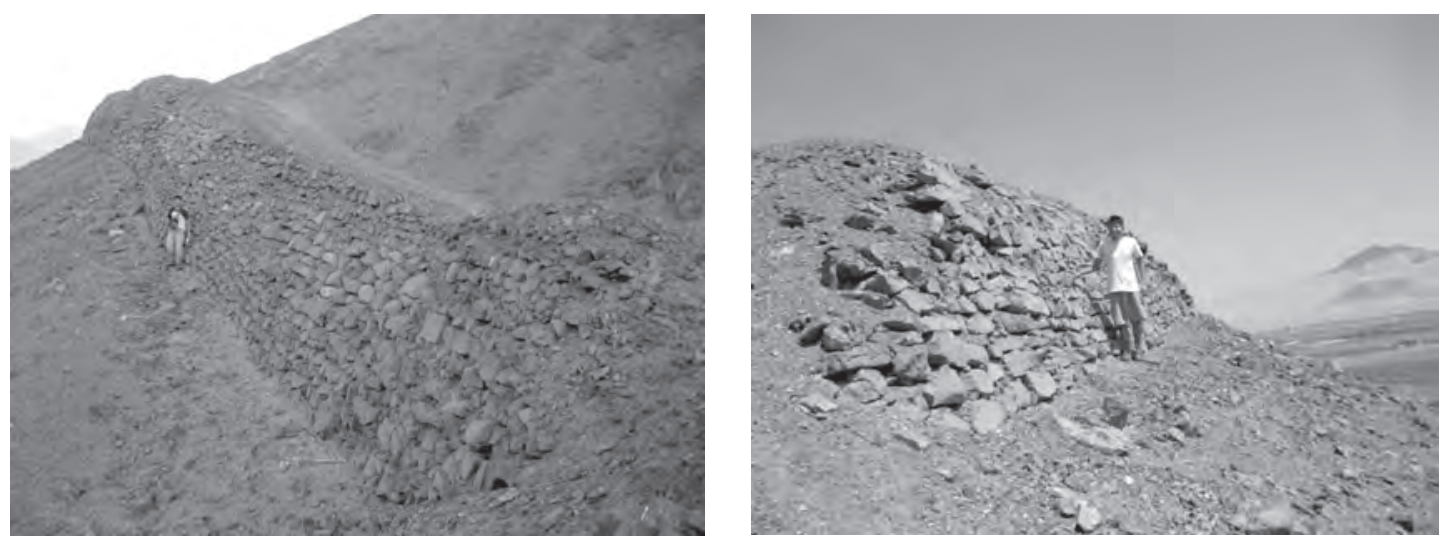

Figura 24 (Izquierda) y Figura 25 (Derecha): Muralla 2, vistas en el lado norte y noroeste, respectivamente

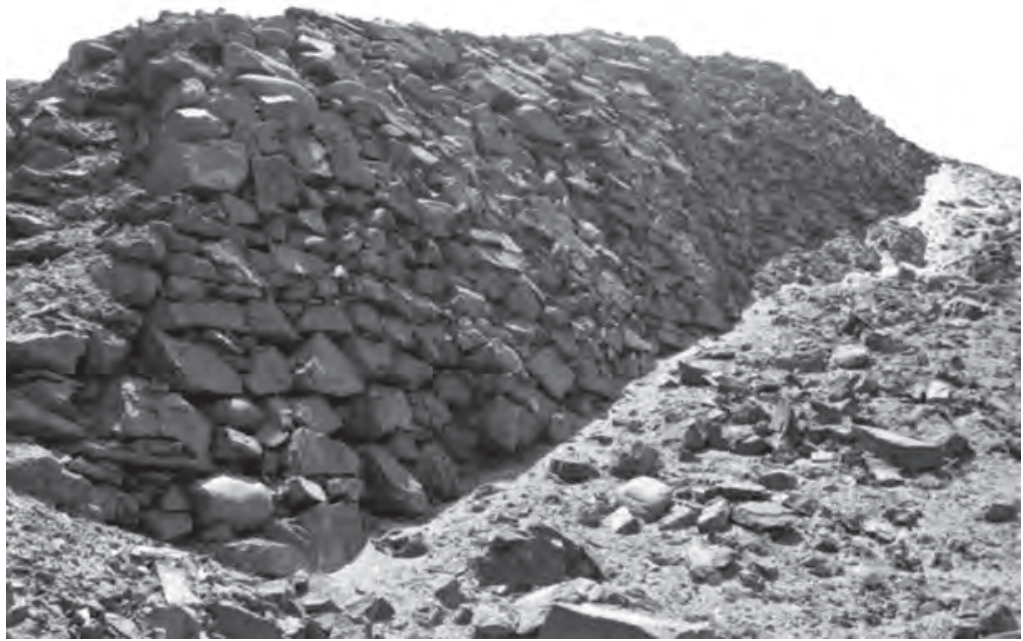

Figura 26: Vista del detalle de la técnica constructiva de la Muralla 2, lado norte 

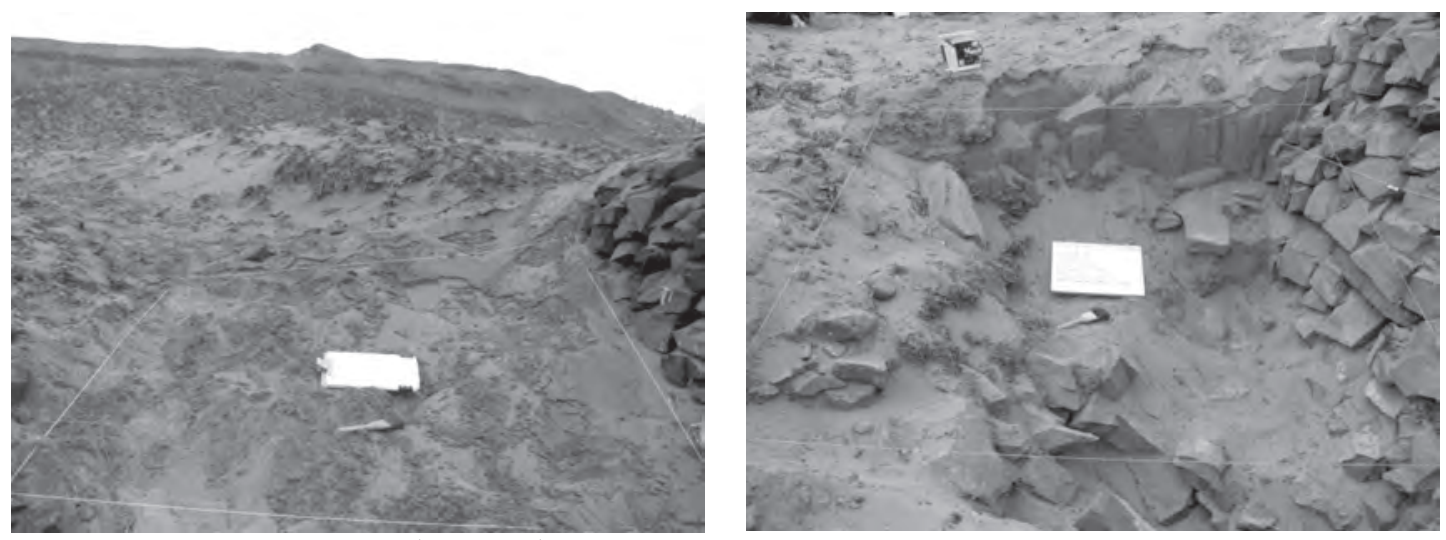

Figura 27 (Izquierda): Capa superficial de la unidad $N^{\circ} 1$ cuadriculada. Figura 28 (Derecha): Final de la excavación, unidad 1.

m. Presenta impregnaciones de material cerámico, botánico y malacológico. En la esquina noreste se pudo encontrar un pequeño depósito de 0,20 m de diámetro conteniendo en su interior restos vegetales: corontas de maíz, carrizo, hojas de lúcuma; y fragmentos de cerámica. Capa B: Capa de tierra compactada entremezclada con piedras de mediano tamaño $(0,15$ a 0,18 m), así como también la presencia de mortero en la parte oriental de la unidad. El color de esta capa es beige claro. Esta capa solo se pudo registrar en la tercera parte de la unidad (lado oriental). El material cultural identificado está compuesto por fragmentería cerámica de pasta naranja, moluscos y material botánico. Capa C: Roca madre, encontrada al oeste de la unidad.

La primera muralla: se ubica en la parte más baja del cerro, en el límite entre este y los campos de cultivo, principalmente de algodón y maíz, muy deteriorado y destruido en algunos tramos (principalmente en el lado septentrional), notándose incluso solo alineamientos de piedras, sin embargo en el lado occidental y meridional se encuentra completo. Presenta una altura de hasta 2,80 $\mathrm{m}$ de alto y un grosor de 1,90 m. Por su parte tiene un largo de $1729,60 \mathrm{~m}$. Ha sido posible identificar el vano de acceso en el lado noroeste del cerro, aunque muy deteriorado. La técnica constructiva consiste de hiladas horizontales de piedras canteadas medianas alternadas con hiladas de hojas de totora dobladas en posición horizontal con los extremos hacia cada paramento, cubiertos a su vez por otra hilada de piedras y estas a su vez por una de vegetales, y así sucesivamente. Hacia el lado oriental de esta muralla, en la parte externa se encuentran los extensos humedales, de donde se obtenía la totora. La totora observada en el muro se presenta doblada simple, o trenzada en "Z" y retorsión en "S". En el lado suroeste
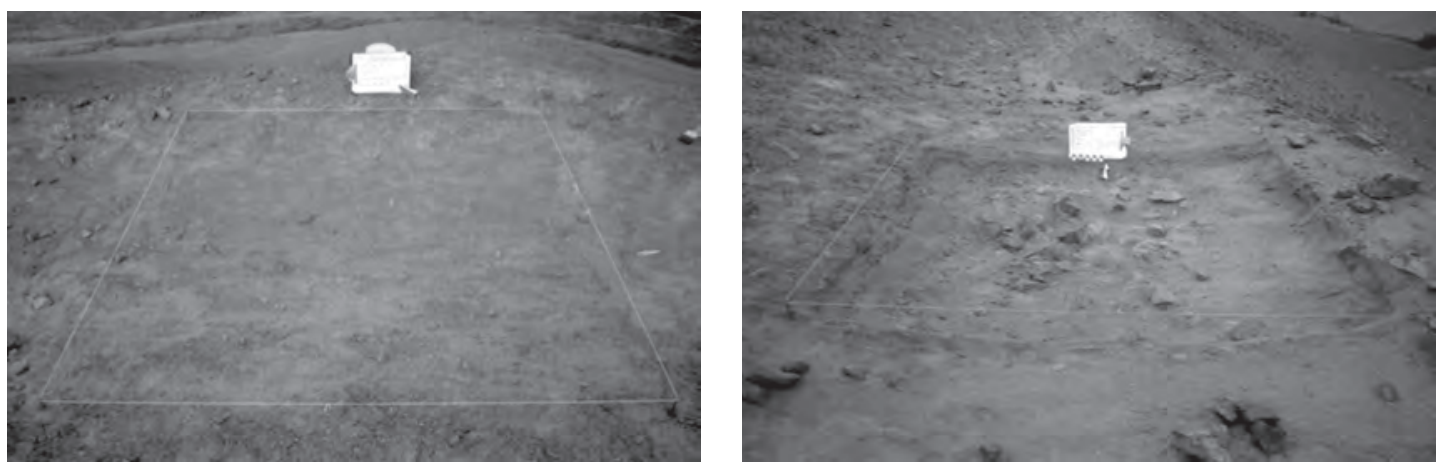

Figura 29 (Izquierda): Capa superficial de la unidad 6. Figura 30 (Derecha): Capa final de la unidad 6 

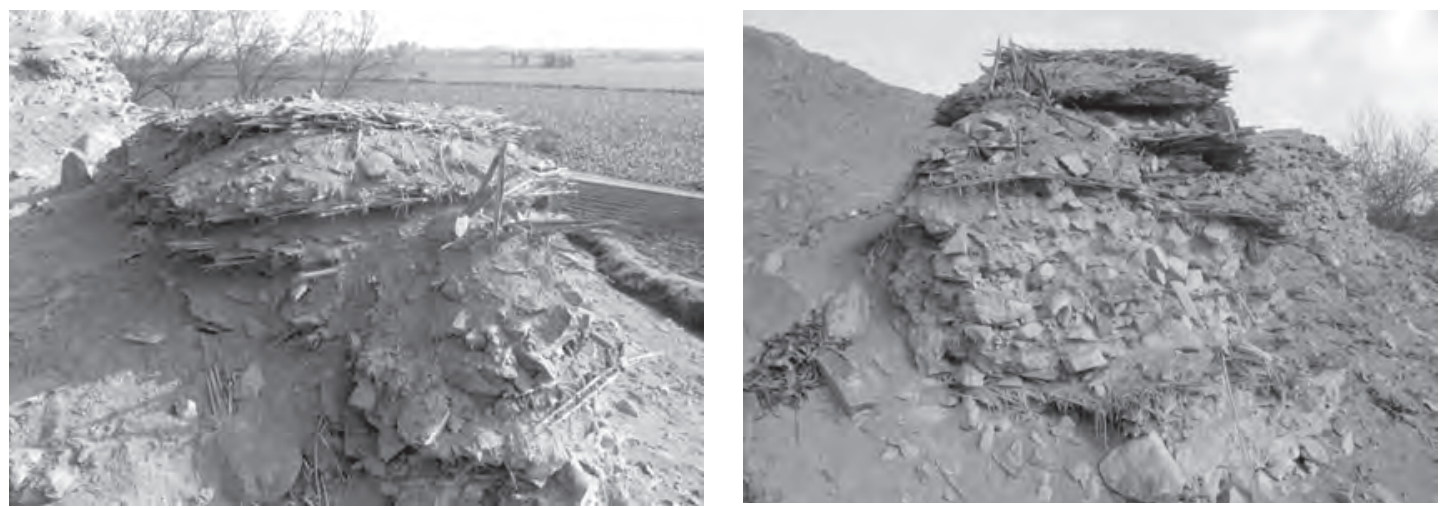

Figura 31 (Izquierda) y Figura 32 (Derecha): Vista de la técnica constructiva de la muralla 1, alternando hileras horizontales de piedras canteadas con tallos de cañas, dispuestos en posición horizontal. Muralla 1, lado Noroeste. del cerro, junto a la primera muralla, en la parte interna, se excavó la unidad 10. La secuencia estratigráfica identificada en esta unidad es la siguiente: Capa S: Capa de arena fina de consistencia suelta y origen eólico, de color beige claro, de 0,05 $\mathrm{m}$ de grosor, entremezclado con piedras grandes producto del colapso de la muralla. En superficie se halló un fragmento textil, moluscos y carbón. Capa A: Capa de tierra suelta, de color beige, y 0,41 $\mathrm{m}$ de grosor. Se encuentra entremezclado con piedras y material botánico. Capa B: Capa de color beige claro, semicompacta, conformada por arena fina entremezclada con adobes (algunos enteros y otros fragmentados). El grosor de esta capa es de 0,12 m. Capa C: Capa de
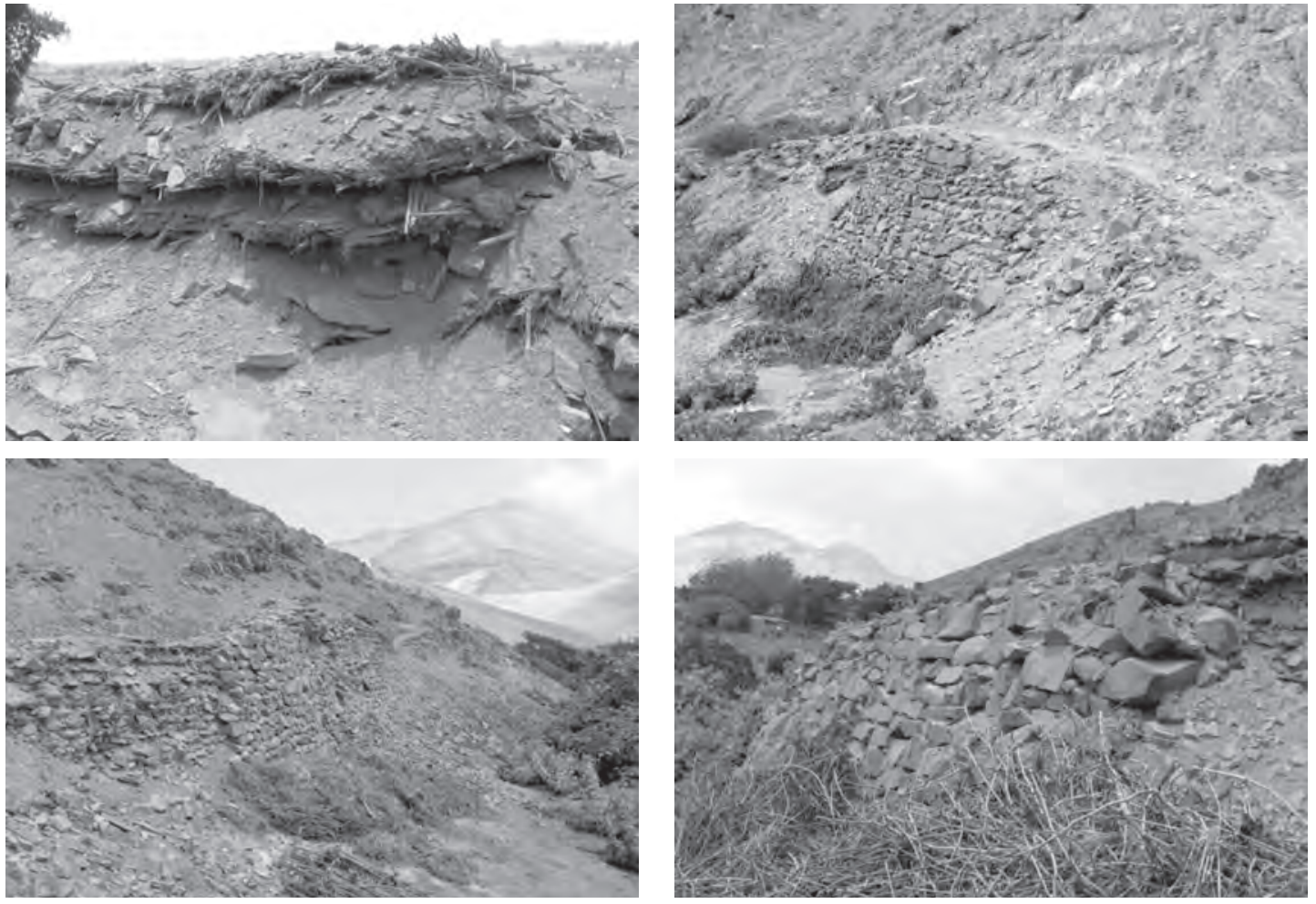

Figura 33 (superior izquierda): Otro detalle de la técnica constructiva de la Muralla 1, lado norte. Figura 34 (superior derecha): Vista panorámica de la Muralla 1 en el lado oeste. Figura 35 (inferior izquierda) y Figura 36 (inferior derecha): Vistas panorámicas de dos tramos de la Muralla 1, vistas en el lado noroeste. 

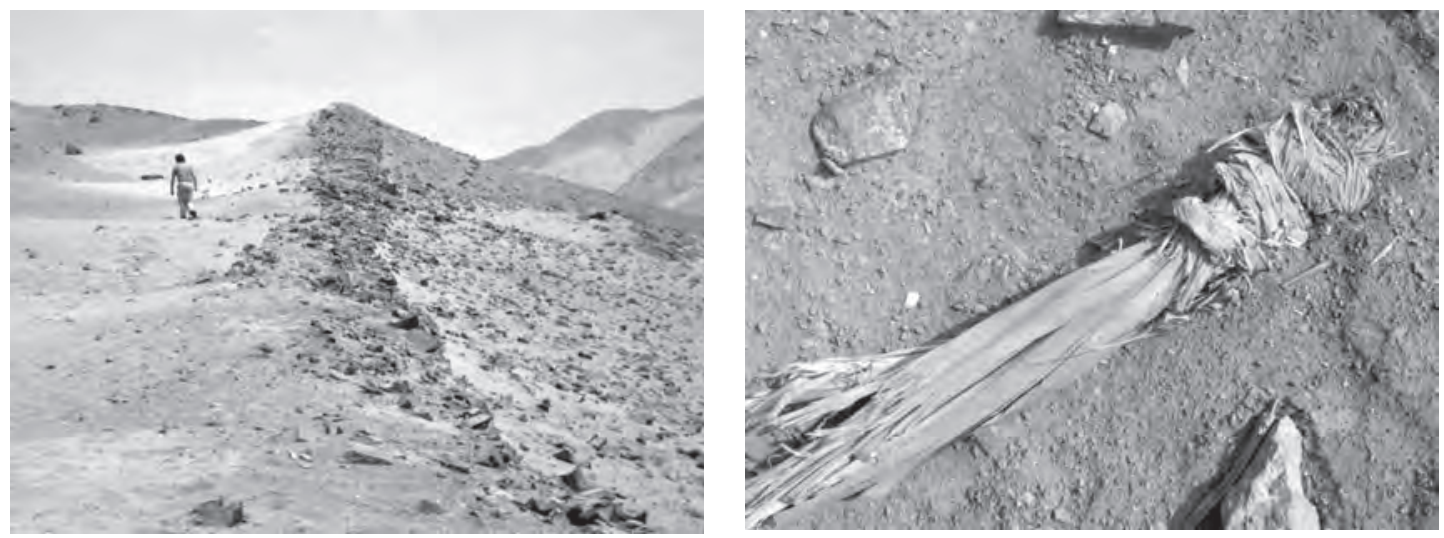

Figura 37 (izquierda): Vista panorámica de la Muralla 1 en el lado sur.

Figura 38 (derecha): Vista de un pedazo de totora hallado en el interior de la Muralla 1

color marrón claro, compuesta de gravilla y arena fina, de consistencia semicompacta. Tiene un grosor de 0,18 m. Capa D: Capa de arena color marrón oscuro, semiconmpacta, entremezclada con abundante totora y carrizo, además de trozos de adobes y un fragmento textil. Tiene un grosor de 0,34 m. Capa E: Apisonado de tierra compacta, de color plomizo con asociación de carrizo unido con soguillas de

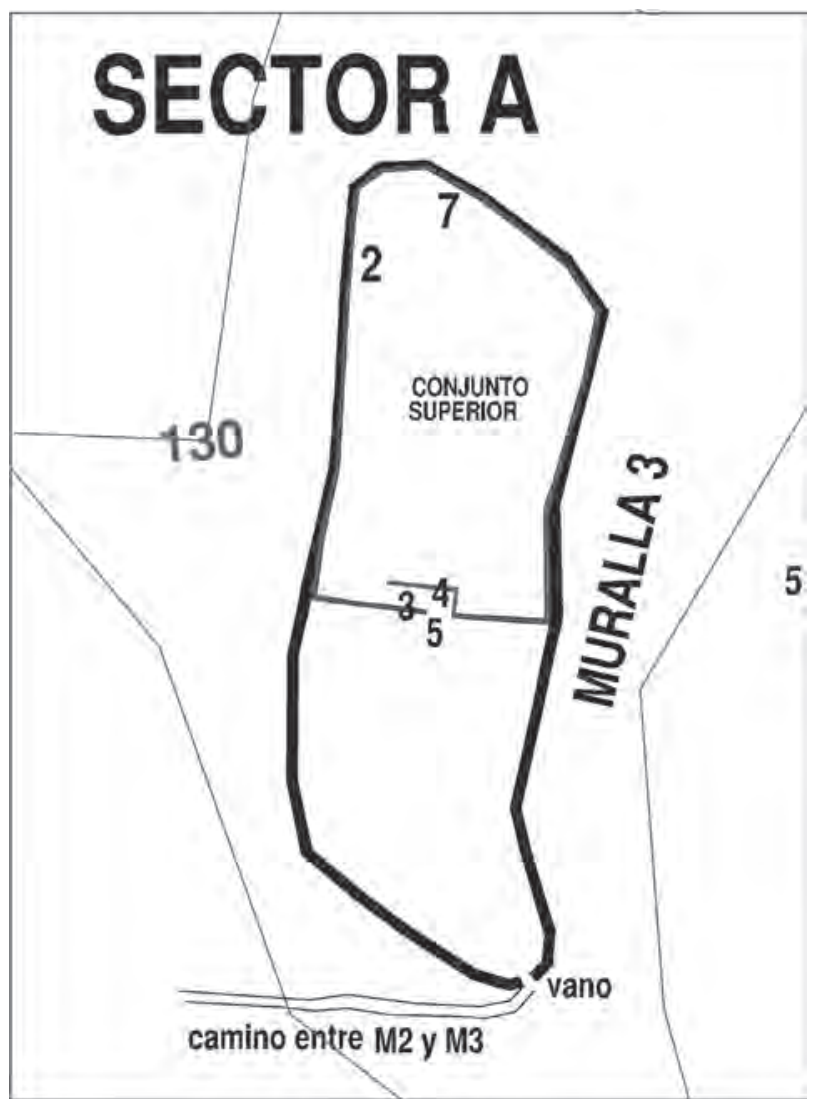

Figura 39: Plano del conjunto superior y la muralla 3. totora. Esta capa tiene un grosor de $0.08 \mathrm{~m}$. Capa F: Capa de tierra compacta, de color plomizo con inclusión de restos botánicos y fragmentos cerámicos. No se culminó la excavación de la unidad por que la arena se deslizaba hacia el interior. Esta capa tiene un grosor de 0,52 m.

2. Sector "B": Ubicado en la parte baja, lado septentrional del cerro, en una pequeña quebrada que desciende desde el cerro hacia los terrenos agrícolas. Se ubica al interior de la muralla 1 y se caracteriza por ser un área funeraria, con un recinto de planta rectangular con muros edifica5 dos con tapiales. Se observa en superficie abundante osamenta humana, así como fragmentería cerámica de pasta roja llana, estilo Chancay en su tipo Negro sobre Blanco y base crema, así como el estilo Lauri Impreso; textiles llanos 2x2 color marrón y restos vegetales (maní, pacae, algodón, maíz). En una prospección del año 2006 se observó una vasija completa de estilo Teatino, olla de cuello mediano. El recinto asociado se ubica inmediatamente al este del área funeraria, sobre una pequeña elevación, es de planta rectangular, muy destruido, con muros edificados a base de tapiales con la técnica de los paños mura- 

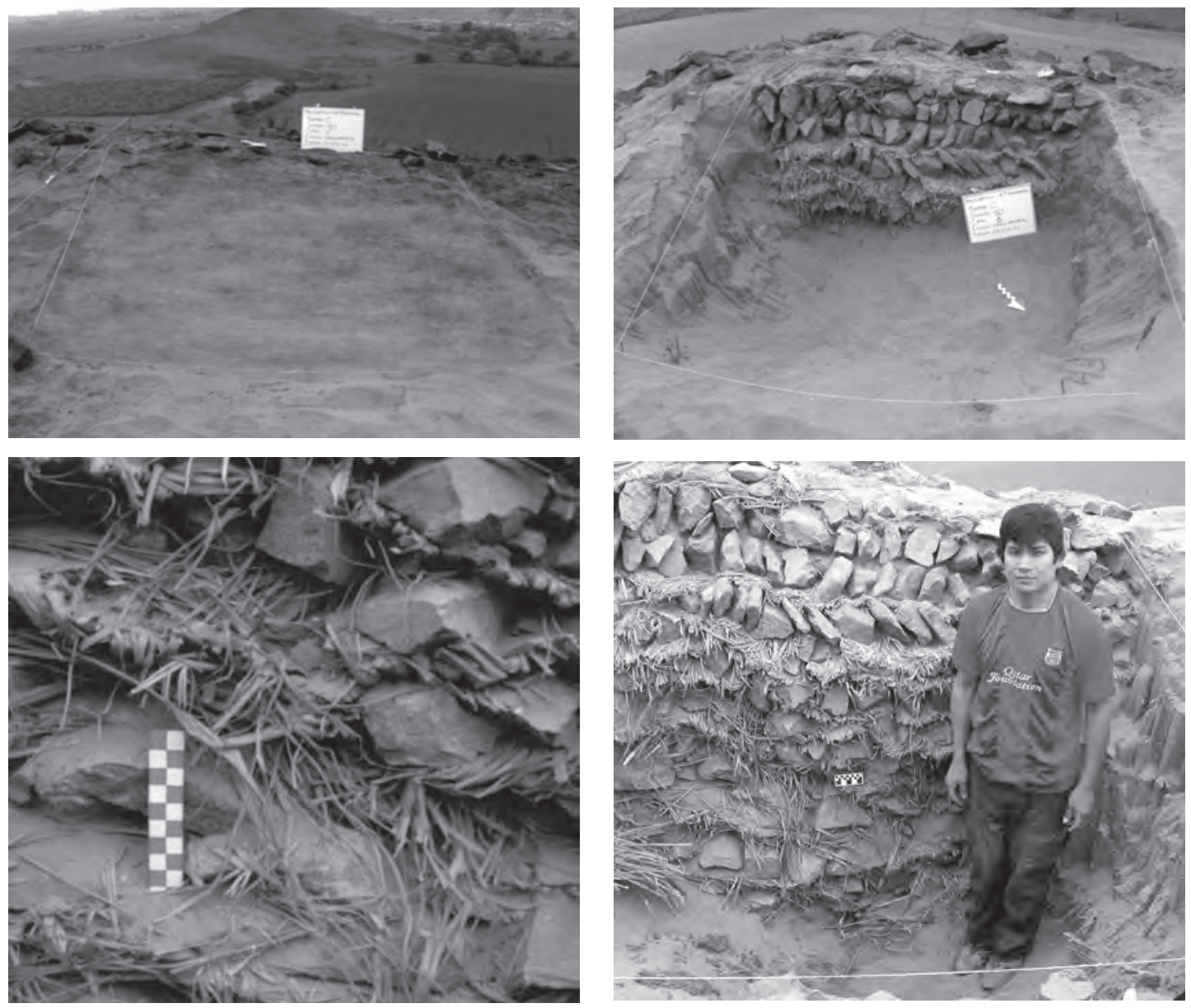

Figura 40 (Superior Izquierda): Vista de la capa superficial de la unidad 10. Figura 41 (Superior Derecha):Vista de la capa C, unidad 10. Figura 42 (Inferior Izquierda): Detalle constructivo de la Muralla 1 identificado en la unidad 10. Figura 43 (Inferior Derecha): Vista del tramo de la muralla 1 identificado en la unidad 10.

rios. El recinto tiene 4.50 metros de ancho por $8,75 \mathrm{~m}$ de largo, con muros de hasta un metro de alto (han colapsado). En el interior del recinto se aprecia material cultural en superficie, conformado por fragmentería cerámica Chancay, restos malacológicos y botánicos. Por la quebrada asciende un estrecho camino que llega a las inmediaciones del vano de la muralla 2, cruzando una pequeña abra en la cual se nota que la roca madre ha sido cortada para descender hacia el lado meridional del cerro en dirección al vano de la muralla 1. Todo el terreno ocupado por el sector B es de naturaleza arenoso.

En medio del sector (área funeraria) se excavó la unidad 8 (UTM: 8716656N, 258565E, WGS-84), la cual fue ampliada en un metro al sur. La secuencia estratigráfica identificada en esta unidad es la siguiente: Capa S: Capa de acumulación eólica de granulometría fina que cubre toda la unidad, de color beige grisáceo, y 0,05 m de grosor. Se identificó materiales culturales en superficie: restos óseos humanos disturbados, pedazos de plástico, latas y papeles. La superficie es uniforme, casi plana, con una pequeña inclinación desde el sur al norte. En la zona colindante al área de excavación se observan restos óseos humanos disturbados (cráneos, tibias, fémures, peroné, sacro, costillas y vertebras). Capa A: Arena suelta de color grisáceo de textura fina, entremezclada con piedrecillas pequeñas y raíces secas. Entre los componentes culturales figuran: fragmentos cerámicos del estilo Chancay, 

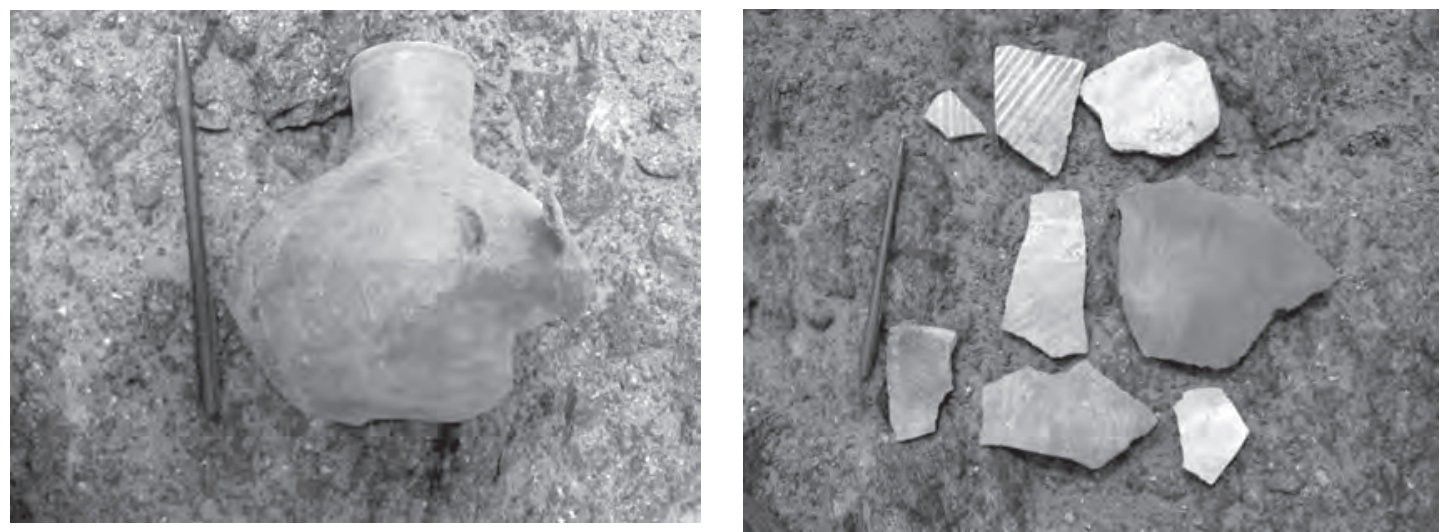

Figura 44 (Izquierda): Vasija Teatino con incisiones lineales y punteadas en el cuello, hallado en superficie del Sector B en un reconocimiento hecho en el sitio el año 2006. Figura 45 (Derecha): Fragmentería cerámica Estilo Chancay negro sobre Blanco y Huaura, visible en superficie del Sector B.
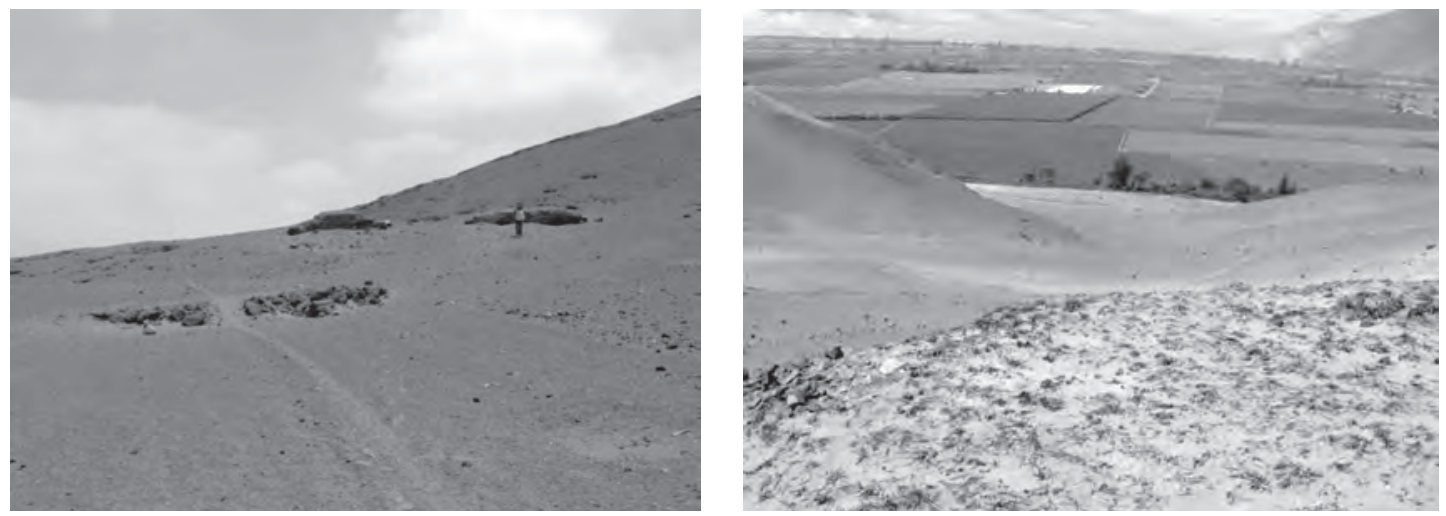

Figura 46 (Izquierda): Vista panorámica del recinto cuadrangular de tapiales del Sector B. Figura 47 (Derecha): Vista panorámica de la quebrada donde se ubica el Sector B.

óseos animales, coprolitos, malacológico y restos vegetales, posiblemente disturbados de la capa inferior. Tiene un grosor de 0,40 m. Capa B: Capa de arena fina de consistencia semisuelta, de color beige, entremezclado con cascajo y materiales culturales como: fragmentos cerámicos, malacológicos y vegetales. Se encontró en el interior de esta capa una esterilla de totora de 1,37 $\mathrm{m}$ de largo y 0,23 $\mathrm{m}$ de alto, de disposición sureste-noroeste. La totora presenta hileras unidas con soguillas de fibra vegetal y se instruye desde esta capa a las siguientes cortando el piso (capa C) y llegando a la capa estéril (capa D). Esta capa tiene un grosor de 0,30 m. Capa C: Piso de arcilla de 0,03 $\mathrm{m}$ de grosor, de color beige, mezclado con piedrecillas pequeñas y de una textura fina. La superficie del piso es pulida y está cubierto por el derrumbe parcial de la esterilla de totoras y restos vegetales entrelazados. El piso cubre la parte sur de la unidad de excavación y su ampliación sur, además está cortada por la esterilla de totoras en el centro de la unidad. Sobre el piso se halló también semillas y coprolitos de roedor (cuy), así como las tenazas de un cangrejo. Capa D: Capa de arena compacta, de color gris, de textura media y culturalmente estéril.

3.- Sector "C": Se ubica en el extremo noroeste del cerro, en la parte baja del cerro, en la parte interna de la Muralla 1, conformado por un recinto de planta rectangular, con muros de tapiales de filiación Chancay. El recinto se emplaza sobre un afloramiento rocoso. El recinto tiene 9,50 $\mathrm{m}$ de largo (eje norte-sur) por 5,40 $\mathrm{m}$ de ancho (eje este-oeste), con muros de hasta $1.80 \mathrm{~m}$ de alto, edificado mediante la técnica de paños murarios, aunque deteriorado en algunas secciones. Presenta un vano deteriorado hacia el lado sur. 

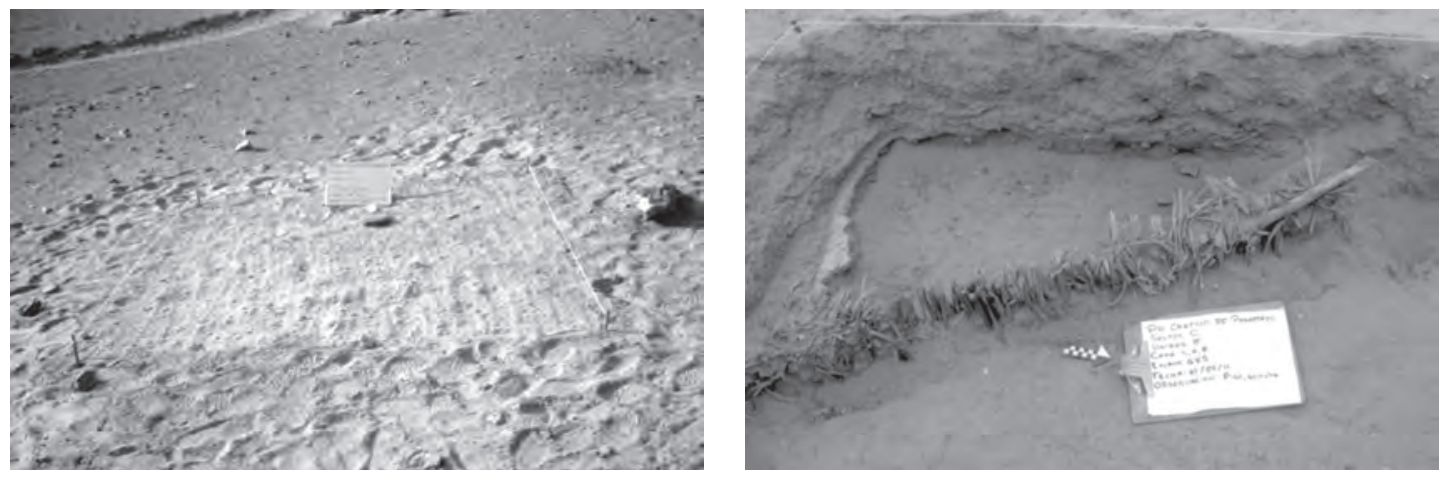

Figura 48 (Izquierda): Imágenes de la capa superficial cuadriculada de la unidad 8. Figura 49 (derecha): Parte del cimiento conformado por totoras entrelazadas horizontales y verticales. Dicho cimiento está dentro de la capa $D$.
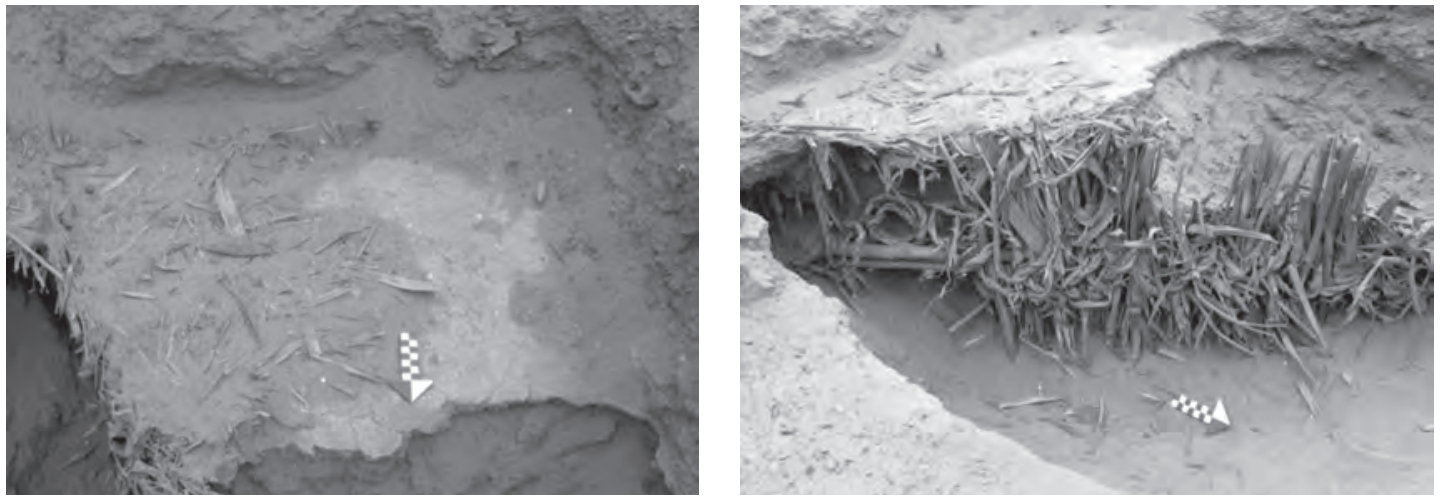

Figura 50 (Izquierda): Detalle del piso, el cual cubre las totoras. Figura 51 (Derecha): La secuencia estratigráfica del piso y las totoras, se ve la sobreposición.

En el interior del recinto de tapiales, a un metro de distancia del muro oriental, se excavó la Unidad 9. La secuencia estratigráfica identificada en esta unidad es la siguiente: Capa S: Capa de arena eólica, de composición suelta, color beige y entre 0,04 y 0,10 m. de grosor. Capa A: Capa de tierra compacta, de color beige claro, entremezclada con piedras desprendidas de la roca madre, de $0,21 \mathrm{~m}$. de grosor. Se encontró en el interior de esta capa restos vegetales en poca proporción (mazorcas de maíz), coprolitos y una vértebra humana. Capa B: Roca madre de origen geológico.
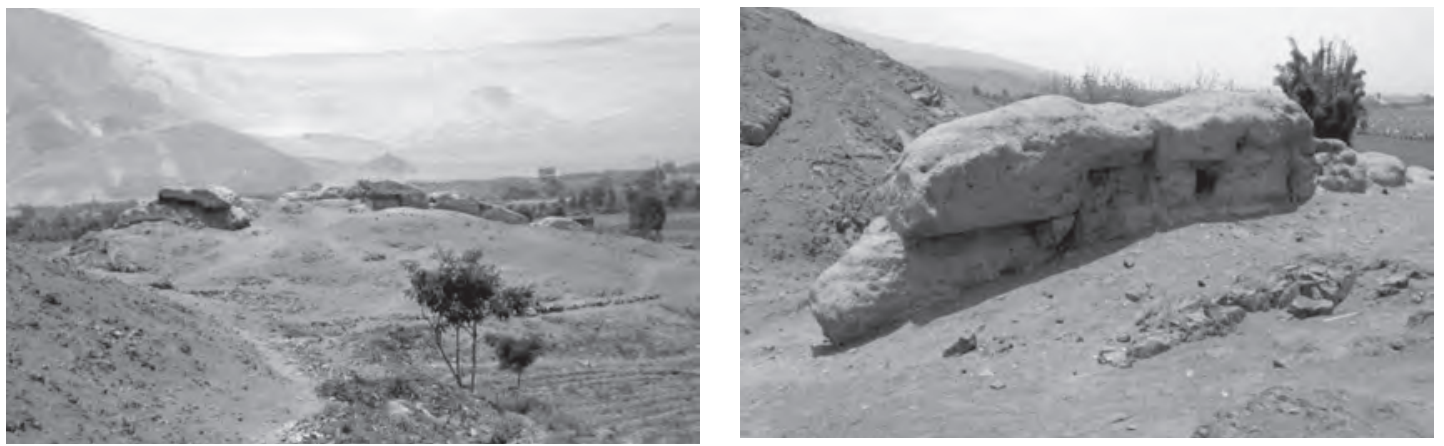

Figura 52 (Izquierda): Vista panorámica del Sector C. Figura 53 (Derecha): Muro del recinto rectangular de tapial, Sector C, en cuyo interior se excavó la unidad 9. 


\section{ANÁLISIS DE LOS MATERIALES CULTURALES RECUPERADOS}

\section{Material Óseo Animal}

Como parte de los análisis desarrollados a los materiales óseos animal se obtuvo los siguientes resultados:

\begin{tabular}{|c|c|c|c|l|}
\hline Unidad & Capa & Especie & Parte & Característica \\
\hline 3 & B & $\begin{array}{c}\text { Phalacrocorax bouganvilli } \\
\text { "guanay" }\end{array}$ & Tibia & $\begin{array}{l}\text { Está fragmentado en cinco partes. Presenta pa- } \\
\text { tología en epífisis distal: Osteomelitis (porosi- } \\
\text { dad) con problemas en parte articular. }\end{array}$ \\
\hline 6 & A & Pescado grande & vértebra & Tiene 1,5 cm de largo. \\
\hline 6 & B & Venado adulto & costilla & $\begin{array}{l}\text { Presenta la diáfisis cuadrangular y el periostio } \\
\text { derecho compactado, está chancado intencio- } \\
\text { nalmente. }\end{array}$ \\
\hline 6 & B & Pescado & vertebras & Dos vertebras pequeñas. \\
\hline 8 & A & Camélido & Esternón & $\begin{array}{l}\text { Cuerpo de esternón de camélido grande y ro- } \\
\text { busto. Se trata de un camélido costeño por el } \\
\text { tipo de tejido esponjoso y abierto. Sería joven } \\
\text { (de 3,5 a 4,5 años). Tiene una protuberancia } \\
\text { ósea (periostitis o cayo óseo), paleopatología } \\
\text { por trabajo de carga. }\end{array}$ \\
\hline 10 & B & Ave marina: gaviota & Húmero & Izquierdo. \\
\hline
\end{tabular}

\section{Material Óseo Humano}

Los materiales óseos humanos fueron recuperados de la unidad 8 (Sector B) y la unidad 4 en el fondo del vano del conjunto superior. Los resultados fueron:

\begin{tabular}{|c|c|c|c|l|}
\hline Unidad & Capa & Especie & Parte & Característica \\
\hline 4 & A & 8 meses & Tibia & Epífisis mordida en dos lados \\
\hline 8 & A & Adulto & $\begin{array}{c}\text { Cráneo, } \\
\text { hueso } \\
\text { frontal }\end{array}$ & $\begin{array}{l}\text { Tiene hiperostosis porótica, debido a una ane- } \\
\text { mia }\end{array}$ \\
\hline
\end{tabular}

\section{Material lítico}

En la unidad 3, capa B, se recuperó un percutor de cuerpo cilíndrico redondeado con desgaste en ambos extremos. Es de granodiorita.

\section{Material Orgánico Animal}

En la unidad 3, capa B y en la unidad 8, capa S, se encontró coprolitos de camélidos.

\section{Material Cerámico}

El material cerámico recuperado de las excavaciones es realmente mínimo. Este material es el siguiente:

A. Estilo Maranga: Se halló un cuerpo decorado (Figura 57: F y 61), caracterizado por presentar pasta naranja y dos líneas horizontales gruesas en color negro.

B. Estilo Huaura: Se encontró un borde (Figura 57: B), correspondiente a un tazón, caracterizado por presentar una línea horizontal en color negro en el labio de la vasija.

C. Estilo Chancay, Tipo Negro sobre Blanco: Se halló un solo cuerpo decorado, con decoración lineal.

D. Estilo Chancay, Tipo Engobe crema: se encontraron varios fragmentos correspondientes a este tipo del estilo Chancay. Un borde de plato (Figura 57: A) y varios cuerpos, incluyendo uno que presenta la aplicación de la cabeza de un mono muy deteriorado, así como otro con una aplicación escultórica de un lobo marino. 
E. Se identificó un borde ligeramente evertido, de pasta negra, cocción reductora (Figura 57: G), de temperantes con granos gruesos: roca molida, cuarzo, entre otros.

F. En la unidad 6 se recuperó nueve fragmentos ( 3 asas, 3 bordes y 3 cuellos), correspondientes a un estilo desconocido, presentan engobe negro o marrón, utilizando como temperantes abundante cuarzo y moluscos de gran tamaño. Son fragmentos muy erosionados y al parecer de periodos culturales tempranos. Las asas son cintadas, una incluso de $3 \mathrm{~cm}$ de ancho.

\begin{tabular}{|c|c|c|c|c|c|c|c|c|c|c|c|}
\hline סृ & 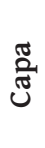 & 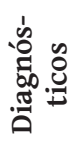 & $\begin{array}{l}\mathscr{d} \\
\frac{0}{0} \\
0 \\
0\end{array}$ & 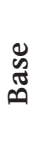 & 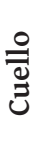 & 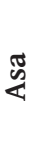 & 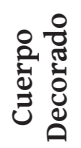 & 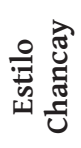 & 율 & 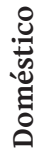 & 莺 \\
\hline 2 & B & 2 & 1 & 1 & & & & & & & 1 \\
\hline 4 & B & 1 & 1 & & & & & & & 1 & \\
\hline 9 & $A$ & 9 & 3 & & 3 & 3 & & & & 9 & \\
\hline 6 & A & 8 & 2 & 1 & & 2 & 3 & 8 & & & \\
\hline 3 & C & 2 & & & & & 2 & 2 & & & \\
\hline 4 & A & 2 & 2 & & & & & & & 2 & \\
\hline 5 & B & 2 & 1 & 1 & & & & & & 2 & \\
\hline 8 & D & 2 & 2 & & & & & & & 2 & \\
\hline 5 & C & 3 & 1 & & & & 2 & 2 & & 1 & \\
\hline 7 & A & 3 & 1 & & & & 2 & 2 & & 1 & \\
\hline 2 & A & 2 & 1 & & 1 & & & & & 2 & \\
\hline 7 & B & 5 & & & & & 5 & 4 & & 1 & \\
\hline 6 & B & 1 & & & 1 & & & & & 1 & \\
\hline 3 & B & 2 & & & 1 & & 1 & & & 2 & \\
\hline 8 & A & 17 & 4 & & 1 & & 12 & 13 & & 4 & \\
\hline
\end{tabular}
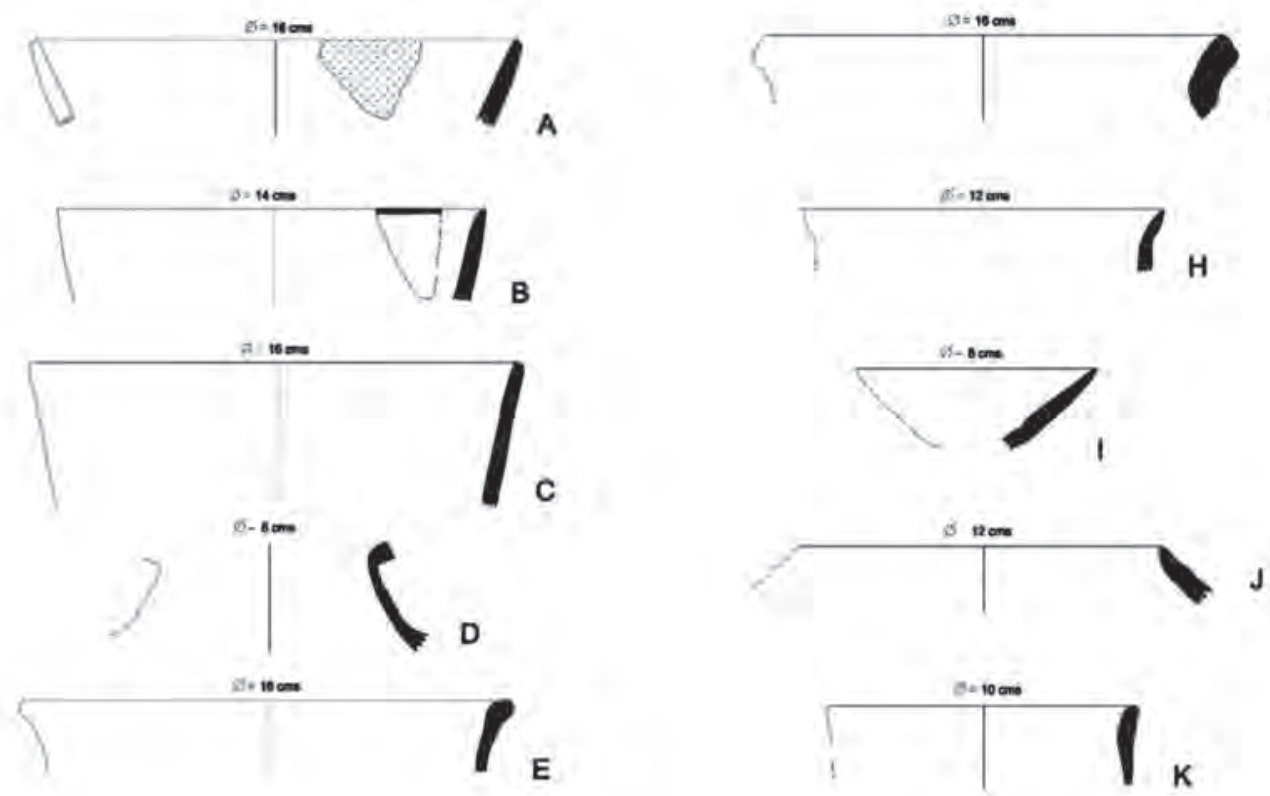

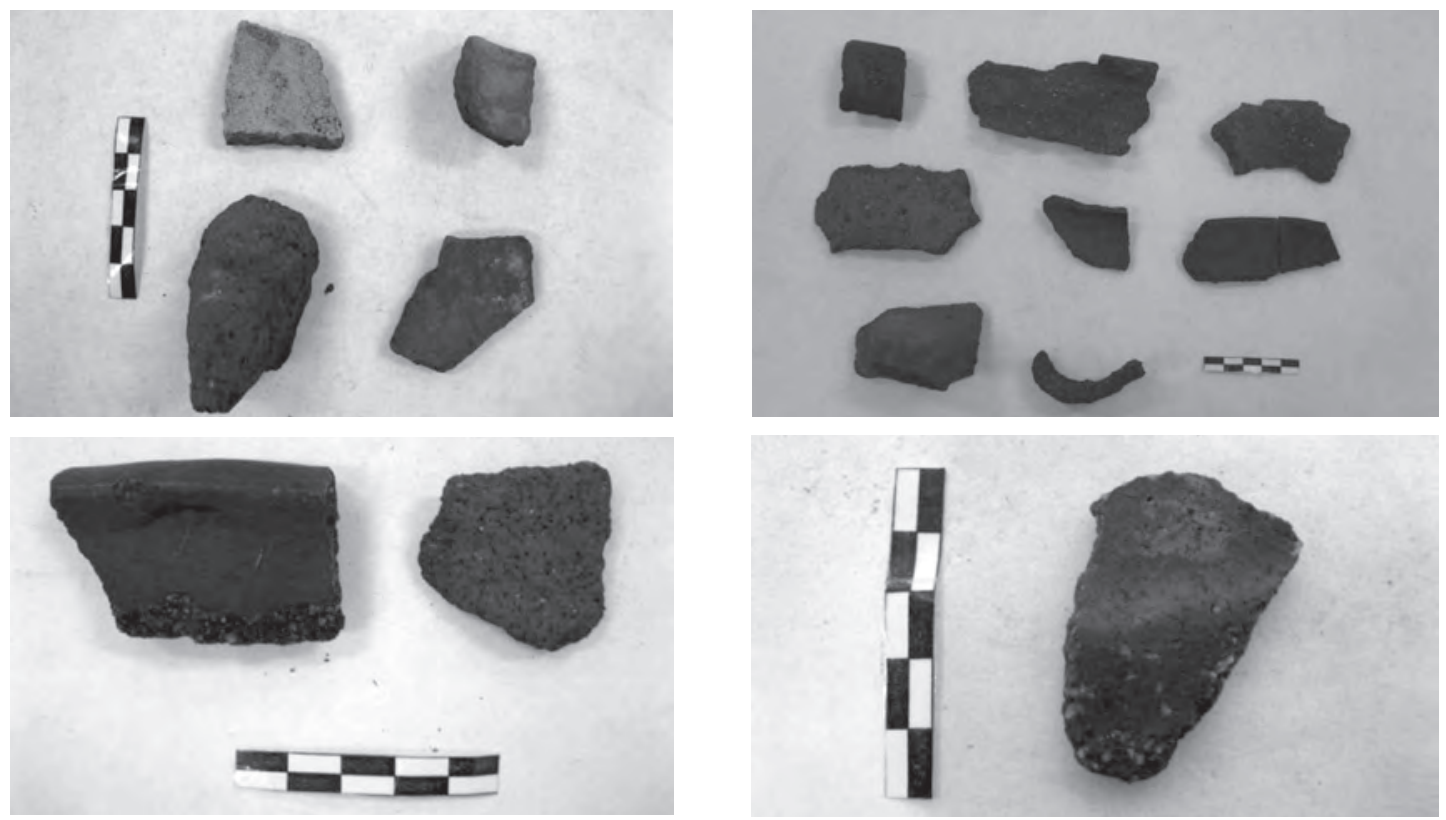

Figura 57 (Superior Izquierda): Fragmentos cerámicos de Estilo Chancay. Figura 58 (Superior Derecha): Fragmentos llanos sin decoración de pasta roja, al parecer corresponderían a un estilo alto andino o de valle medio. Figura 59 (Inferior Izquierda): Izquierda, fragmento de pasta negra, cocción reductora (Figura 57: G, Derecha, fragmento de pasta roja. Figura 60 (Superior Derecha): Fragmentos de Estilo Maranga, con decoración en bandas negras gruesas sobre fondo naranja.

\section{Material malacológico}

De los análisis realizados entre los materiales malacológicos identificados durante las excavaciones se obtuvo los siguientes resultados:

Tabla2: Cálculo del Número mínimo de Individuos y Número de restos

\begin{tabular}{|c|c|c|c|c|c|c|c|}
\hline $\begin{array}{l}\mathrm{N}^{\circ} \\
\text { bolsa }\end{array}$ & Sector & Unidad & Capa & Especies de moluscos & NMI & NR & PESO \\
\hline \multirow[t]{9}{*}{1} & A & 3 & B & Mesodesma donacium & 1 & 24 & 30 \\
\hline & & & & Choromytilus chorus & 1 & 1 & 5 \\
\hline & & & & Perumytilus purpuratus & 1 & 1 & 1 \\
\hline & & & & Argopecten purpuratus & 1 & 2 & 7 \\
\hline & & & & FAMILIA SEMELIDAE & 1 & 2 & 4 \\
\hline & & & & Thais chocolata & 2 & 2 & 36 \\
\hline & & & & Thais delessertiana & 1 & 1 & 4 \\
\hline & & & & Crepipatella dilatata & 7 & 7 & 14 \\
\hline & & & & Tegula atra & 1 & 1 & 1 \\
\hline 2 & A & 2 & D & Argopecten sp. & 1 & 3 & 6 \\
\hline \multirow[t]{4}{*}{3} & A & 5 & A & Choromytilus chorus & 1 & 1 & 3 \\
\hline & & & & Perumytilus purpuratus & 1 & 1 & 1 \\
\hline & & & & FAMILIA SEMELIDAE & 1 & 1 & 5 \\
\hline & & & & Crepipatella dilatata & 2 & 2 & 6 \\
\hline 4 & A & 4 & A & Mesodesma donacium & 1 & 1 & 1 \\
\hline
\end{tabular}


Arqueología y Sociedad 24, 2012: 301-332

\begin{tabular}{|c|c|c|c|c|c|c|c|}
\hline & & & & Choromytilus chorus & 1 & 1 & 2 \\
\hline & & & & Crepipatella dilatata & 1 & 1 & 3 \\
\hline \multirow[t]{3}{*}{5} & A & 2 & A & Mesodesma donacium & 1 & 1 & 2 \\
\hline & & & & Choromytilus chorus & 1 & 1 & 6 \\
\hline & & & & Thais delessertiana & 2 & 2 & 6 \\
\hline \multirow[t]{6}{*}{6} & $\mathrm{~A}$ & 7 & A & Mesodesma donacium & 2 & 17 & 34 \\
\hline & & & & Choromytilus chorus & 1 & 1 & 1 \\
\hline & & & & Perumytilus purpuratus & 1 & 1 & 1 \\
\hline & & & & Protothaca thaca & 1 & 1 & 5 \\
\hline & & & & Crepipatella dilatata & 2 & 2 & 5 \\
\hline & & & & Crustaceo no identificado & 1 & 2 & 1 \\
\hline \multirow[t]{3}{*}{7} & A & 5 & B & Mesodesma donacium & 1 & 12 & 19 \\
\hline & & & & Crepipatella dilatata & 6 & 6 & 14 \\
\hline & & & & Thais chocolata & 1 & 1 & 3 \\
\hline \multirow[t]{12}{*}{8} & C & 8 & A & Mesodesma donacium & 1 & 15 & 39 \\
\hline & & & & Choromytilus chorus & 1 & 3 & 5 \\
\hline & & & & Argopecten purpuratus & 1 & 1 & 3 \\
\hline & & & & Aulacomya ater & 1 & 1 & 4 \\
\hline & & & & Sememytilus algosus & 2 & 3 & 2 \\
\hline & & & & FAMILIA SEMELIDAE & 1 & 1 & 10 \\
\hline & & & & Crepipatella dilatata & 4 & 4 & 9 \\
\hline & & & & Thais chocolata & 2 & 2 & 9 \\
\hline & & & & Fissurella latimarginata & 1 & 1 & 7 \\
\hline & & & & Fisurella sp. & 1 & 1 & 4 \\
\hline & & & & Tegula sp. & 1 & 1 & 1 \\
\hline & & & & FAMILIA CHITONIDAE & 1 & 1 & 1 \\
\hline \multirow[t]{10}{*}{9} & Ninguno & 7 & B & Mesodesma donacium & 2 & 17 & 16 \\
\hline & & & & Choromytilus chorus & 1 & 1 & 2 \\
\hline & & & & Argopecten sp. & 1 & 1 & 4 \\
\hline & & & & FAMILIA SEMELIDAE & 2 & 6 & 11 \\
\hline & & & & Crepipatella dilatata & 7 & 7 & 21 \\
\hline & & & & Thais chocolata & 1 & 1 & 3 \\
\hline & & & & Fissurella crassa & 1 & 1 & 4 \\
\hline & & & & Tegula sp. & 1 & 1 & 1 \\
\hline & & & & FAMILIA CHITONIDAE & 1 & 2 & 4 \\
\hline & & & & Crustaceo no identificado & 1 & 1 & 3 \\
\hline \multirow[t]{8}{*}{10} & $\mathrm{C}$ & 8 & $\mathrm{D}$ & Mesodesma donacium & 3 & 8 & 44 \\
\hline & & & & Choromytilus chorus & 4 & 8 & 73 \\
\hline & & & & Perumytilus purpuratus & 2 & 2 & 4 \\
\hline & & & & Sememytilus algosus & 2 & 2 & 4 \\
\hline & & & & FAMILIA SEMELIDAE & 1 & 1 & 9 \\
\hline & & & & Thais chocolata & 2 & 2 & 17 \\
\hline & & & & Crepipatella dilatata & 2 & 2 & 9 \\
\hline & & & & Prisogaster niger & 3 & 3 & 18 \\
\hline \multicolumn{5}{|r|}{ TOTAL : } & 99 & 199 & 567 \\
\hline
\end{tabular}


Pieter van Dalen / Investigaciones arqueológicas en el Castillo de Pasamayo

Tabla 3: Cálculo del Número mínimo de Individuos y Número de restos

\begin{tabular}{|l|c|c|c|}
\hline Especies de moluscos & NMI & NR & PESO \\
\hline Mesodesma donacium & 12 & 95 & 185 \\
\hline Choromytilus chorus & 11 & 17 & 97 \\
\hline Perumytilus purpuratus & 5 & 5 & 7 \\
\hline Argopecten purpuratus & 2 & 3 & 10 \\
\hline Argopecten sp. & 2 & 4 & 10 \\
\hline Aulacomya ater & 1 & 1 & 4 \\
\hline Sememytilus algosus & 4 & 5 & 6 \\
\hline Protothacathaca & 1 & 1 & 5 \\
\hline FAMILIA SEMELIDAE & 6 & 11 & 39 \\
\hline Thais chocolata & 8 & 8 & 68 \\
\hline Thais delessertiana & 3 & 3 & 10 \\
\hline Crepipatella dilatata & 31 & 31 & 81 \\
\hline Fissurella latimarginata & 1 & 1 & 7 \\
\hline Fissurella crassa & 1 & 1 & 4 \\
\hline Tegula atra & 1 & 1 & 1 \\
\hline Prisogaster niger & 3 & 3 & 18 \\
\hline Fisurella sp. & 1 & 1 & 4 \\
\hline Tegula sp. & 2 & 2 & 2 \\
\hline FAMILIA CHITONIDAE & 2 & 3 & 5 \\
\hline Crustáceo no identificado & 2 & 3 & 4 \\
\hline \multicolumn{1}{|c|}{ TOTAL } & 99 & 199 & 567 \\
\hline
\end{tabular}

Tabla 4: Cálculo de porcentajes del material malacológico

\begin{tabular}{|l|c|c|c|c|c|c|}
\hline Especies de moluscos & NMI & \% NMI & NR & \% NR & PESO & \% PESO \\
\hline Mesodesma donacium & 12 & $12 \%$ & 95 & $48 \%$ & 185 & $33 \%$ \\
\hline Choromytilus chorus & 11 & $11 \%$ & 17 & $9 \%$ & 97 & $17 \%$ \\
\hline Perumytilus purpuratus & 5 & $5 \%$ & 5 & $3 \%$ & 7 & $1 \%$ \\
\hline Argopecten purpuratus & 2 & $2 \%$ & 3 & $2 \%$ & 10 & $2 \%$ \\
\hline Argopecten sp. & 2 & $2 \%$ & 4 & $2 \%$ & 10 & $2 \%$ \\
\hline Aulacomya ater & 1 & $1 \%$ & 1 & $1 \%$ & 4 & $1 \%$ \\
\hline Sememytilus algosus & 4 & $4 \%$ & 5 & $3 \%$ & 6 & $1 \%$ \\
\hline Protothaca thaca & 1 & $1 \%$ & 1 & $1 \%$ & 5 & $1 \%$ \\
\hline FAMILIA SEMELIDAE & 6 & $6 \%$ & 11 & $6 \%$ & 39 & $7 \%$ \\
\hline Thais chocolata & 8 & $8 \%$ & 8 & $4 \%$ & 68 & $12 \%$ \\
\hline Thais delessertiana & 3 & $3 \%$ & 3 & $2 \%$ & 10 & $2 \%$ \\
\hline Crepipatella dilatata & 31 & $31 \%$ & 31 & $16 \%$ & 81 & $14 \%$ \\
\hline Fissurella latimarginata & 1 & $1 \%$ & 1 & $1 \%$ & 7 & $1 \%$ \\
\hline Fissurella crassa & 1 & $1 \%$ & 1 & $1 \%$ & 4 & $1 \%$ \\
\hline Tegula atra & 1 & $1 \%$ & 1 & $1 \%$ & 1 & $0 \%$ \\
\hline Prisogaster niger & 3 & $3 \%$ & 3 & $2 \%$ & 18 & $3 \%$ \\
\hline Fisurella sp. & 1 & $1 \%$ & 1 & $1 \%$ & 4 & $1 \%$ \\
\hline Tegula sp. & 2 & $2 \%$ & 2 & $1 \%$ & 2 & $0 \%$ \\
\hline FAMILIA CHITONIDAE & 2 & $2 \%$ & 3 & $2 \%$ & 5 & $1 \%$ \\
\hline Crustáceo no identificado & 2 & $2 \%$ & 3 & $2 \%$ & 4 & $1 \%$ \\
\hline TOTAL & 99 & $100 \%$ & 199 & $100 \%$ & 567 & $100 \%$ \\
\hline
\end{tabular}




\section{Material Botánico}

Entre el material botánico recuperado de las excavaciones figuran:

Tabla 5: Tabla de restos botánicosidentificados en las excavaciones

\begin{tabular}{|c|c|c|c|c|}
\hline Unidad & Capa & Nombre común & Nombre científico & Parte de la planta \\
\hline 1 & $\mathrm{~A}$ & Achupalla & Tillandsia sp. & Tallos y hojas \\
\hline 2 & $\mathrm{D}$ & Pacae & Inga feullai & Fruto y tronco quemado \\
\hline 3 & B & Tara & Caesalpinia tara & Tallos \\
\hline 4 & A & Totora & Thypa angustifolia & Tallos \\
\hline 4 & A & Achupalla & Tillandsia sp. & Tallos y hojas \\
\hline 5 & $\mathrm{~B}$ & Achupalla & Tillandsia sp. & Tallos y hojas \\
\hline 6 & A & Maíz & Zea mayz & tusas \\
\hline 6 & A & Totora & Thypa angustifolia & Tallos \\
\hline 6 & A & Caña brava & Gynerium sagitatum & Tallos \\
\hline 6 & $\mathrm{~B}$ & Maíz & Zea mayz & tusas \\
\hline 6 & $\mathrm{~B}$ & Totora & Thypa angustifolia & Tallos \\
\hline 6 & B & Caña brava & Gynerium sagitatum & Tallos \\
\hline 6 & B & Pacae & Inga feullai & hojas \\
\hline 8 & A & Maíz & Zea mayz & Tusas y tallos \\
\hline 8 & $\mathrm{~B}$ & Totora & Thypa angustifolia & Tallos \\
\hline 8 & $\mathrm{~B}$ & Caña brava & Gynerium sagitatum & Tallos \\
\hline 8 & C & Algodón & Gosipium barbadensis & Fibra y semillas \\
\hline 8 & $\mathrm{D}$ & Totora & Thypa angustifolia & Tallos \\
\hline 8 & $\mathrm{D}$ & Maíz & Zea mayz & Tuzas \\
\hline 9 & A & Maíz & Zea mayz & Tuzas \\
\hline 9 & A & Algarrobo & Prosopis sp. & Tallos \\
\hline 9 & A & Pacae & Inga feullai & hojas \\
\hline 10 & $\mathrm{~S}$ & Totora & Thypa angustifolia & Tusas \\
\hline 10 & $\mathrm{~S}$ & Achupalla & Tillandsia sp. & Tallos y hojas \\
\hline 10 & $\mathrm{C}$ & Algodón & Gosipium barbadensis & Semilla \\
\hline 10 & E & Totora & Thypa angustifolia & Tallos \\
\hline
\end{tabular}

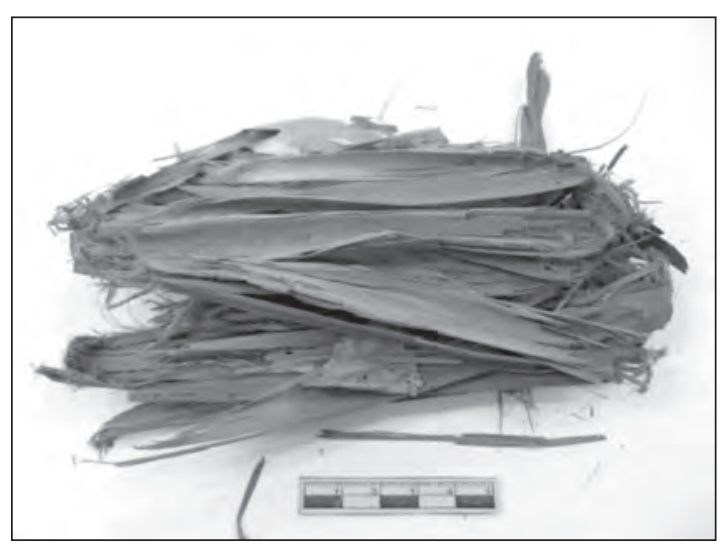

Figura 61: Tallos de totora recuperados de las excavaciones

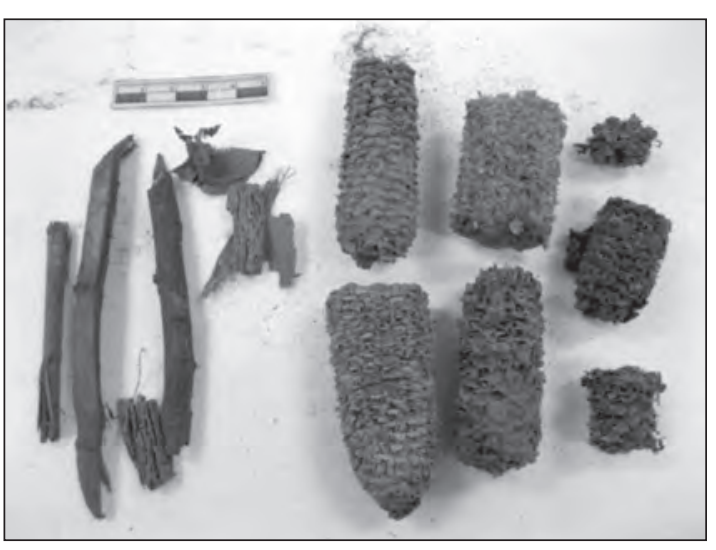

Figura 62: Tallos y tusas de maíz. 


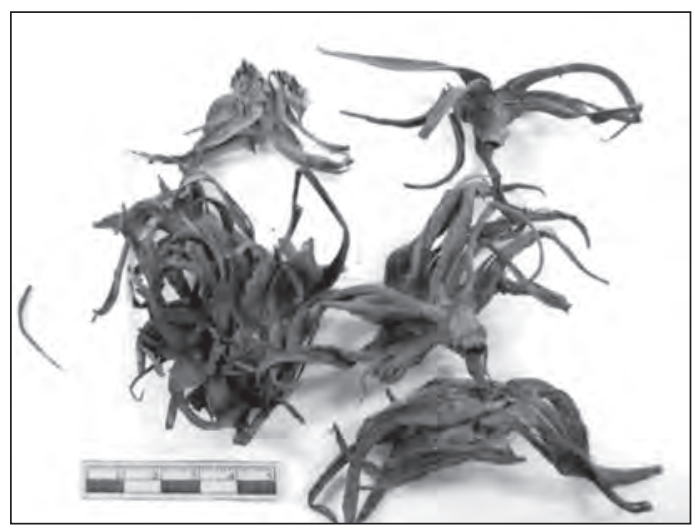

Figura 63: Tallos y flores de Achupalla.

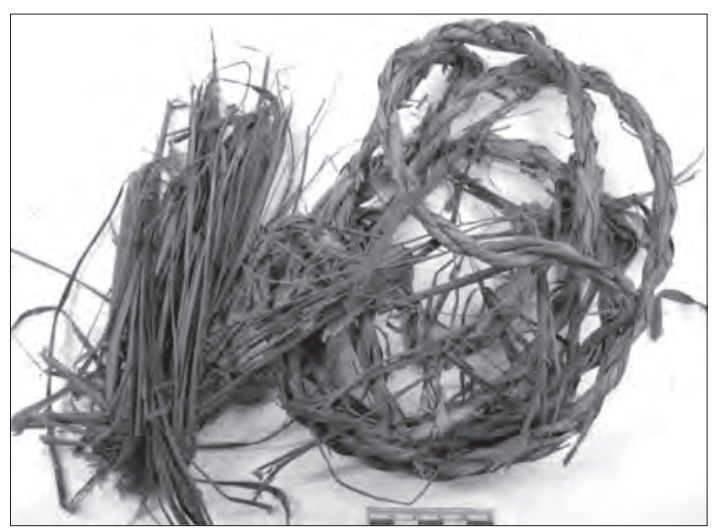

Figura 64: Tallos de totora trenzados recuperado de las excavaciones en asociación a la muralla 1 (unidad 10)

\section{DISCUSIÓN Y CONCLUSIONES PRELIMINARES}

Ha sido posible identificar en el sitio Castillo de Pasamayo tres sectores: El sector A, ubicado en la parte superior y media del cerro, conformado por el conjunto superior ubicado en la cima del cerro, circundado por un muro perimétrico de piedras canteadas, con una banqueta interna adosada de adobes. El acceso al conjunto superior es en "L", orientado al oeste. Debajo de la cima circundan tres murallas edificadas a base de capas horizontales de piedras canteadas y retsos vegetales (totora, achupalla o cañas). El sector B, se ubica en una pequeña quebrada que desciende hacia el lado norte, conformada por una pequeña área funeraria Chancay y un recinto de planta rectangular con muros de tapiales en mal estado de conservación (parte interna de la muralla 1). El sector C se ubica en la esquina noroeste del cerro, en la parte baja, junto a los terrenos agrícolas, fuera de la muralla 1, conformado por un recinto Chancay de planta rectangular, emplazado sobre un promontorio rocoso, y con los muros edificados en la técnica del tapial.

Las excavaciones en el sector A, en el vano e interior del conjunto superior permitieron definir la temporalidad del sector, correspondiente al Intermedio Tardío (cultura Chancay). La secuencia estratigráfica está conformado por una capa de origen eólico, de aproximadamente entre 0,05 y 0,08 m (capa superficial); la capa A, conformado por el derrumbe de los muros, conformado por piedras canteadas entremezcladas con tierra de color gris. Luego hay una capa conformada por un piso, elaborado de barro compactado de aproximadamente $0,08 \mathrm{~m}$ de grosor; una capa de tierra semicompacta preparatoria para la elaboración del piso y la roca madre. No hay una larga secuencia, las capas son de poco grosor. Los materiales asociados, son principalmente botánicos y escasos fragmentos Chancay, fragmentos llanos de textura serrana, y un fragmento Lima. Se identificó también material malacológico, principalmente Mesodesma donacium, Choromytilus chorus y Perumytilus purpuratus. Entre los principales productos botánicos figura la totora, la achupalla y el maíz. Se halló además restos óseos de aves guaneras y algunos de camélidos, algunos caracterizados por presentar paleopatologías.

Las excavaciones en el sector B, en el área funeraria Chancay dio como resultado el hallazgo de un área disturbada, con un piso de barro semicompacto, y una esterilla dispuesta en posición vertical colocada sobre la capa estéril, muy deteriorada. Se halló abundante fragmentería cerámica perteneciente al estilo Chancay en su tipo negro sobre blanco y llano; así como escasos restos óseos disturbados.

Las excavaciones en el sector $C$, definió una delgada secuencia estratigráfica al interior del recinto de tapias, conformado por un piso de barro compacto y sobre este una capa (Capa A) de origen eólico. El piso se emplaza inmediatamente sobre el afloramiento rocoso. 
Lamentablemente la poca dimensión de las unidades no ha permitido tener un mejor panorama sobre los contextos y asociaciones, por lo que una segunda temporada de excavaciones con unidades en área permitirá ampliar el panorama sobre este sitio.

Sobre la funcionalidad de este y otros sitios similares en los valles de Chancay y Huaura, hay varias propuestas. Para los sitios del Horizonte Temprano ubicados al norte del valle de Huaura, Dagget (1987) propone que las "fortalezas" del Horizonte Temprano pudieron haber sido indicativos de intentos de cohesión social, al proveer visibilidad entre los distintos sitios de un valle. Shelia Pozorski (1987), Proulx $(1973,1985)$ y Wilson $(1987,1988,1995)$ los asocian con acciones de guerra. Por su parte Iván Ghezzi (2006) los define como templos fortificados, sin negar el papel del conflicto (Brown 2010: 176). Por su parte Brown señala sobre estos sitios del valle de Huaura que: "En lugar de representar una manifestación de conflictos internos del valle entre comunidades, la distribución de los mismos podría implicar una correlación con la ubicación de las quebradas (donde había rutas de acceso al valle siguiente al Norte: El Supe), y podrían haber servido para controlar la entrada al valle a través de esas rutas de acceso laterales. Las fortificaciones podrían reflejar una preocupación por alguna amenaza externa (fuera del valle), en lugar de una interna" (Ibid: 178). Brown define la misma configuración espacial y arquitectónica de los sitios tempranos, así como la reocupación de estos en el Intermedio Tardío, dejando entrever alguna posible conexión entre los sitios tardíos con el avance Chimú a los valles ubicados al Sur del Casma, a fin de controlar el agua (ibid: 186); sin embargo en el sitio Castillo de Pasamayo no se ha encontrado ni un solo fragmento cerámico de estilo Chimú, tampoco Brown lo reporta en las excavaciones en Acaray y sus fechados obtenidos (al menos el primero) no coinciden con la fecha aproximada de avance Chimú a los valles de Chancay y Huaura (aproximadamente 1450 d.C.).

Identificar la funcionalidad y el papel que cumplieron estos sitios amurallados en los valles de Chancay y Huaura es un poco complicado y confuso. Sin embargo creemos que de ninguna manera están asociados a guerras, al menos en cuanto a los de datación Tardía. Sin embargo se han registrado extensas murallas que sí habrían cumplido la función de evitar el avance de huestes enemigas, como las de Mazo en el valle de Huaura, encargado de evitar el avance Chimú y las de Huayán (Villar 1982: 245) y Lumbra en el valle medio del río Chancay (van Dalen 2010).

Por nuestra parte pensamos y planteamos a modo de hipótesis que la función que tuvo el sitio Castillo de Pasamayo fue de carácter religioso. La ubicación de este sitio al igual que muchos otros del valle Chancay denota cierta diferenciación del resto de asentamientos tardíos. Es visible desde todo el sector Sur del valle Chancay-Huaral, lo que le da importancia entre los ayllus del sector. Pues los sitios ceremoniales se caracterizan por estar ubicados en puntos estratégicos y que denotan respeto entre los pobladores locales. Mircea Eliade señala que en los lugares ceremoniales o religiosamente sagrados, se desarrollaron revelaciones primordiales, son lugares que destacan en el paisaje o son lugares donde se desarrollaron hechos importantes (Eliade 2000: 522). En el reconocimiento de los materiales superficiales y en las excavaciones, no se han encontrado armas o proyectiles, que nos permitan pensar que se trata de un asentamiento defensivo.

La gran incógnita es ¿Por qué la arquitectura del conjunto superior y murallas circundantes son a base de piedras y elementos vegetales?, cuando todos los sitios Chancay circundantes son a base de adobes y tapiales. Cabe la posibilidad de que el sitio haya sido edificado por poblaciones Chancay del valle medio o de poblaciones de la sierra, pues las poblaciones Chancay del valle medio se caracterizan por presentar sus edificaciones a base de piedras canteadas, en algunos casos alternadas con adobes y muchos sitios ceremoniales se ubican en la cima del los cerros conformados por pequeños y pocos recintos rectangulares o irregulares delimitados por muros perimétricos igualmente a base de piedras. Además en muchos de estos sitios hay una gran densidad de material cerámico perteneciente al estilo Lauri Impreso o Quillahuaca, estilo de manufactura en el valle medio y cuenca alta. De ser así, cabe la posibilidad de que estos sitios se hayan constituido en sitios pertenecientes a ayllus alto o medio andinos, de función religiosa, destinados al culto al mar, a la puesta del sol o incluso como enlaces administrativos de los enclaves ecológicos, para el aprovechamiento de productos de litoral; pues los 
documentos etnohistóricos hacen referencia de grupos altoandinos de Chilca que poseían algunas playas del litoral chancayano para aprovisionamiento de sus ayllus nucleares (Rostworowski 2005: 123), aunque se trata de una referencia colonial. En las áreas funerarias del valle medio se puede encontrar diseminados numerosos implementos para pesca (Cuyo, Lumbra, San Miguel, Huataya, etc). Si se tratara de sitios religiosos o adoratorios al mar o a la puesta del sol, o a alguna entidad religiosa, serían el antecedente de otros sitios de tal función que los Incas van a edificar junto al mar, como el Cerro La Horca en el valle de Fortaleza. Por otra parte de tratarse de murallas con fines limitantes, el objetivo de estos serían solo aislar la cima, sin importar la estética o materiales constructivos, los muros serían levantados como usualmente lo hacían para otros sitios del valle, sin denotar un simbolismo arquitectónico o estético. La existencia de sitios religiosos cercados por impresionantes muros ha sido registrado para algunos sitios andinos (Saqsaywamán, Pachacámac), en la India (Mohenjo Daro), como de la Costa del Egeo en el Viejo Mundo. El cercado de un área ceremonial no solo implica y significa la presencia continuada en su interior de una cratofanía o de una hierofanía, sino busca proteger y aislar lo sagrado de lo profano; pues lo sagrado es peligroso para todos aquellos que ingresan a su ámbito sin una debida preparación, sin los movimientos de "acercamiento" mediante acto religioso o litúrgico. De igual manera en el caso de las ciudades cercadas, el cerco o muralla, cumple más que una función defensiva, el aislamiento de las áreas urbanas de los aspectos mágicos que viven fuera de la urbe, y que pueden resultar perjudiciales a las personas, incluyendo las enfermedades, epidemias, pestes, malos espíritus, $u$ otros (Eliade 2000: 525-526). Por otra parte, las actividades ceremoniales no se restringen a recintos ceremoniales, templos o plazas, sino que fueron desarrollados en lugares domésticos, agrarios, viales y funerarios. La mayoría de actividades religiosas no son rastreadas por los arqueólogos, pues se confunden con las actividades domésticas (Scott 1994: 28).

El uso de restos vegetales en los muros, como se ha observado en el caso de las murallas del Castillo de Pasamayo, no ha sido registrado para otros sitios contemporáneos del valle. En el análisis arquitectónico que realiza Sandra Negro sobre los sitios Chancay, se definen dos tipos de muros en base a los materiales constructivos: los edificados con adobes y los de piedra canteada unida con argamasa, pudiendo ser muros simples pero en su mayoría dobles con un relleno interno de tierra, piedras y hasta fragmentería cerámica, no mencionando los restos vegetales (Negro 1991). Van Dalen por su parte, describe como las especies arbóreas del valle eran aprovechadas como elementos constructivos (van Dalen 2011). Sin embargo Margaret Brown describe la misma técnica de las murallas del Castillo de Pasamayo, en las murallas de Acaray, con capas alternas entre material vegetal y piedras, con relleno de piedra, basura y tierra (Brown 2010: 182). Las murallas del Castillo de Pasamayo no son rectas, sino presentan el paramento externo inclinadas hacia dentro, en promedio de $110^{\circ}$, cada una con un solo vano de acceso y un camino zigzagueante que los comunica, ya que los accesos no se encuentran orientados. Las murallas cumplen la función de restringir el acceso a los ambientes superiores, constituyéndose en un muro de contención y a la vez en camino epimural. En este sentido definimos que las murallas no solo cumplen función defensiva, sino también de aislamiento de espacios sagrados.

Futuras investigaciones con excavaciones, especialmente en todo el conjunto superior, nos permitirán definir con mayor detalle las características funcionales de este sitio, de gran importancia para la comprensión de la arqueología tardía del valle Chancay; así como nos permitirán validar o desechar las hipótesis planteadas.

\section{Reconocimientos y agradecimientos}

En este espacio es necesario reconocer y agradecer a las personas y profesionales que han participado desinteresadamente en el presente proyecto. El señor Gerson Marcelo Mellado y la señora Marita Marcelo Mellado, apoyaron en el registro del sitio el año 2006. Las excavaciones se realizaron con la participación de los estudiantes de VII Ciclo de la EAP de Arqueología de San Marcos, como parte del curso de Métodos en Arqueología II, participando el Lic. Martín Ronald Rodríguez Huaynate como 
Jefe de Campo, el Bach. John Hurtado Quintanilla como asistente de campo y Gino Marcelo M. como ayudante de campo. Los planos estuvieron a cargo del Ing. Luis Portugal. Los análisis del material óseo animal y humano fueron realizados por el Dr. Alfredo Altamirano, el material malacológico por la Arqueóloga Roxana Paucar Manzanilla y el material lítico por el Bach. Edwin Silva. Un agradecimiento muy especial a todos ellos. Entre los estudiantes que participaron durante las excavaciones figuran: Hans Grados R., Juan Narro A., Ricardo Guevara T., Marco Guerrero M., Rosario Torres G., Rosa Carlos I., Leonard Salazar J., Martín Núñez A., Rodolfo Valencia, Alejandro Picardo, Kevin Salazar, entre otros.

\section{BiBLIOGRAFÍA}

AGURTO CALVO, Santiago y Alfredo SANDOVAL

1974 Inventario, catastroy delimitación del patrimonio arqueológico del valle del río Chancay. Instituto Nacional de Cultura. Manuscrito. Lima.

ALMEIDA REYES, Eduardo

1999 Estudios arqueológicos en el Pucará de Rumichuco. Banco Central del Ecuador. Museo Nacional. Guayaquil, 220 p.

BROWN VEGA, Margaret

2009 "Prehispanic warfare during the Early Horizon and Late Intermediate period in the Huaura Valley, Peru". Current Anthropology, No 50 (2). Pp: 255-266.

2010 "Regional patterns of fortification and single forts: Evaluating the articulation of regional sociopolitical dynamics with localized phenomena. En Comparative perspectives on the Archaeology of Coastal South America. Eds. Cutright, R., Hurtado López, E., and A. Martin. Pittsburgh: Center for Comparative Archaeology, University of Pittsburgh; Lima: Fondo Editorial, Pontificia Universidad Católica del Perú; Quito: Ministerio de Cultura del Ecuador. Pitsburg, Pp. 169-189.

BROWN VEGA, Margaret; Nathan CRAIG y Gerbert ASENCIOS LINDO

2011 "Ground truthing of remotely identified fortifications on the Central Coast of Peru". Journal of Archaeological Science $N^{\circ} 38$ (7): 1680-1689.

COLÁN, Hermógenes; Domingo DíAZ y Jorge MONTALVO

1936 "Estudios arqueológicos en el valle de Chancay" En: Album de Oro Huaralino. T.II Jorge Montalbo, editor. Ed. Mora. Lima pp. 136-142.

CORNEJO GUERRERO, Miguel

1985 Análisis del material cerámico excavado por Hans Horkheimer en 1961, Lauri, Valle de Chancay. Memoria para optar al grado de Bachiller (Tesis). PUCP, Facultad de Letras y Ciencias Humanas. Lima.

DILLEHAY, Tom

1974 Competition and cooperation in a prehispanic multi-etnic system in the central Andes. Tesis doctoral, University of Texas-Austin.

ELIADE, Mircea

1998 Lo sagrado y lo profano. Barcelona: Ed. Paidós. 191 Pp.

2000 Tratado de historia de las religiones. Morfología y dialéctica de lo sagrado. Madrid: Ediciones Cristiandad. $658 \mathrm{Pp}$.

ENGEL, Fréderic

1987 De las begonias al maíz: vida y producción en el antiguo Perú. Lima: Centro de Investigaciones de Zonas Aridas. Universidad Nacional Agraria.

GHEZZI, Iván y Clive RUGGLES

2006 "Las trece torres de Chankillo: Arqueoastronomía y organización social en el primer observatorio solar de América" Boletín de Arqueología PUCP. º 10: 215-236. Lima: Pontificia Universidad Católica del Perú. Andina, $\mathrm{N}^{\circ} 44:$ 199-225. Cusco. 
GUTIÉRREZ, José y Patricia SUÁREZ MANJÓN

2007 "Castillos y fortalezas feudales en Asturias: Metodología para su estudio". En: Territorio, sociedad y poder. $\mathrm{N}^{\circ}$ 2. Madrid, $31 \mathrm{pp}$.

HORKHEIMER, Hans

1965 “Identificación y bibliografía de importantes sitios prehispánicos del Perú” En: Arqueológicas № 8 Lima: Museo Nacional de Arqueología y Antropología.

KRZANOWSKI, Andrzej

1991 Estudios sobre la cultura Chancay-Perú. Krakow: Polonia.

2008 Kultura Chancay. Srodkowe wybrzezé Perú. Instytut Amerykanistyki i studiów Polonijnych. Uniwersytetu Jagiellonskiego. Krakow, $225 \mathrm{Pp}$.

MORALES CHOCANO, Daniel

1998 Compendio histórico del Perú. Del Paleolítico al Imperio Inca. Tomo I. Lima: Ed. Milla Batres. 670 Pp.

NEGRO, Sandra

1991 "Arquitectura y sistemas constructivos en los asentamientos de la cultura Chancay" En: Estudios sobre la cultura Chancay-Perú. Krakow. Pp. 57-82.

ONERN

1969 Inventario, evaluación y uso racional de los recursos naturales de la Costa: Valle Chancay-Huaral. Lima: Oficina Nacional de Evaluación de Recursos Naturales (ONERN) II Tomos.

POZORSKI, Thomas

1987 "Chavín, the early Horizon and the initial period". The origins and development of the Andean State. J. Haas, S.G. Pozorski y T. Pozorski, editors. Cambridge: University Press Cambridge, Pp. 36-46.

PROULX, Donald

1973 "Archaeological investigations in the Nepeña valley, Perú". Research report, $\mathrm{N}^{\circ} 13$. University of Massachusetts, $292 \mathrm{Pp}$.

1985 "Ananalysis of the early cultural sequence of the Nepeña valley, Perú". Research report, №25. University of Massachusetts, 359 Pp.

RENFREW, Colin y Paul BAHN

1998 Arqueología. Teoría, métodos y práctica. Segunda edición. Madrid: Ed. Akal. 571 Pp.

ROSAS CUADROS, Emilio

1976 Historia de la provincia de Huaral. Lima.

ROSTWOROWSKI DE DIEZ CANSECO, María

2005 Recursos naturales renovables y pesca, siglos XVI-XVII. Lima: Instituto de Estudios Peruanos. 123 p.

SCOTT RAIMOND, J.

1994 "La vida ceremonial en el Formativo Temprano de Ecuador" El Mundo Ceremonial Andino. Lima: Ed. Horizonte. Pp. 27-46.

TELLO ROJAS, Julio C.

2004 "La muralla de Santa". Arqueología y Sociedad. N 15: 11-32. Lima: Museo de Arqueología y Antropología. Universidad Nacional Mayor de San Marcos. Lima.

VALKENIER, Lisa

1995 "New evidence for Chimu Capac and the early horizon period in the Supe valley, Peru". Journal of the steward anthropological society, Current research in Andean antiquity. № 23 (1-2): 269-286. Urbana Champaign.

VAN DALEN LUNA, Pieter

2002 Estudios de la arquitectura en el sitio arqueológico de Cuyo, valle medio del río Chancay. Informe final presentado al Instituto Nacional de Cultura, $167 \mathrm{Pp}$.

2004a "Arqueología y etnohistoria de los periodos tardíos en la provincia de Huaral". Revista del Centro de Estudiantes de Arqueología. Lima: Universidad Nacional Mayor de San Marcos. Pp. 22-48.

2004 b "Los valles de Huaura y Chancay dentro del imperio del Tahuantinsuyo" En: Boletín del patronato de defensa del patrimonio cultural de los valles de Huaura y Ambar. № 16, año III, Junio. Pp. 3 - 8 
2005 "Proceso cultural Prehispánico en Chancayllo, valle de Chancay KULLPI. Investigaciones culturales en la provincia de Huaral y el Norte Chico. Año 2, No 2, mayo, Huaral. Pp. 55 - 75.

2007a "Reconocimiento arqueológico en la cuenca alta del río Chancay - Huaral: margen izquierda (distritos de Atavillos Alto, Santa Cruz de Andamarca y Pacaraos). Nuevos datos para comprender los procesos socio- culturales Atavillos." KULLPI. Investigaciones culturales en la provincia de Huaral y el Norte Chico. Año 3, No 3, Mayo, Huaral, Pp. 50 - 130.

$2007 b$ "Resultado de las Investigaciones arqueológicas en Pampa de Animas, valle de Huaura". Guara. Revista del Museo Arqueológico de la UNJFSC. № 3. Huacho, Pp. 16-24.

2008 Los ecosistemas arqueológicos en la cuenca baja del río Chancay-Huaral: Su importancia para el desarrollo de las formaciones sociales prehispánicas. Ed. Gutemberg. Lima, 196 Pp.

2009 "Sistemas de asentamiento en el valle medio del río Chancay" KULLPI. Investigaciones culturales en la provincia de Huaral y el Norte Chico. Año 4, No 4, Octubre. Huaral, Pp. 217 - 294.

2010 "Análisis de un documento de extirpación de idolatrías procedente del complejo arqueológico Lumbra, valle medio del río Chancay-Huaral”. Investigaciones Sociales, № 24. Instituto de Investigaciones Histórico Sociales. Facultad de Ciencias Sociales. Universidad Nacional Mayor de San Marcos. Lima, Pp 85-105.

2011a "El uso de la madera en la cultura Chancay". KULLPI. Investigaciones culturales en la provincia de Huaral y el Norte Chico. Año 5, No 5, Agosto. Lima, Pp. 59 - 74.

2011 b "El Tawantinsuyu en la costa norcentral peruana: valles de Chancay y Huaura" Investigaciones Sociales, № 27. Instituto de Investigaciones Histórico Sociales. Facultad de Ciencias Sociales. Universidad Nacional Mayor de San Marcos. Diciembre del 2011. Lima, Pg. 77-104.

VILLAR CORDOVA, Pedro

1982 [1935] Arqueología del departamento de Lima. Segunda Edición. Lima: Ed. Atusparia.

WATANABE DE AMANO, Rosa

1996 "La trascendencia de los sitios arqueológicos" En: Boletín de actividades Fundación Museo Amano. Año 6, № 8, Lima 4 Pp.

WILLEY, Gordon

1953 "Prehistoric settlements patterns in the Virú Valley, Perú". Bureau of American Ethnology Bulletin. $\mathrm{N}^{\circ}$ 155, Washington D.C.: Smithsonian Institute Press. 453 Pp.

WILSON, David

1988 Prehistoric Settlement patterns in the lower Santa Valley, Perú: A regional perspective on the origins and development of complex North Coast Society. Washington D.C.: Smithsonian Institution Press. 590 Pp.

1997 "Early state formation on the North Coast of Perú: A critique of the city state model". The archaeology of city states: Cross cultural approaches. Washington D.C.: Smithsonian Institution Press. Pp. 229244. 